INFLUENCE OF CATCHMENT AND STREAM CHARACTERISTICS ON SUSPENDED SOLIDS AND PHOSPHORUS CONCENTRATIONS ACROSS AN AGRICULTURALLY INTENSIVE WATERSHED IN SOUTHERN ONTARIO

\author{
By \\ Arsh Grewal \\ H. Ba., Ryerson University, 2017 \\ A thesis presented to Ryerson University \\ in partial fulfillment of the requirements for the degree of \\ Master of Spatial Analysis in the program of \\ Spatial Analysis
}

Toronto, Ontario, Canada, 2019

(C)Arsh Grewal, 2019 


\section{Author's Declaration}

AUTHOR'S DECLARATION FOR ELECTRONIC SUBMISSION OF A THESIS I hereby declare that I am the sole author of this thesis. This is a true copy of the thesis, including any required final revisions, as accepted by my examiners. I authorize Ryerson University to lend this thesis to other institutions or individuals for the purpose of scholarly research. I further authorize Ryerson University to reproduce this thesis by photocopying or by other means, in total or in part, at the request of other institutions or individuals for the purpose of scholarly research. I understand that my thesis may be made electronically available to the public 


\title{
INFLUENCE OF CATCHMENT AND STREAM CHARACTERISTICS ON SUSPENDED SOLIDS AND PHOSPHORUS CONCENTRATIONS ACROSS AN AGRICULTURALLY INTENSIVE WATERSHED IN SOUTHERN ONTARIO
}

By Arsh Grewal, MSA in Spatial Analysis, Ryerson University, 2019

\begin{abstract}
The overall objective of this study is to determine the influence of landscape and hydrological characteristics on sub-catchment variability of total phosphorus (TP), soluble reactive phosphorus (SRP), the ratio of SRP and TP (SRP/TP), and total suspended solids (TSS). Fourteen longitudinal synoptic surveys were conducted for 13 sampling sites over a variety of flow conditions in the Innisfil Creek watershed located in southern Ontario. The surveys were split into baseflow and stormflow and partial least squares regression (PLSR) was used to analyze the relationship between watershed and hydrological characteristics, median concentrations of phosphorus, and TSS. The PLSR models indicate that buried tile drainage might be a major source of SRP in Innisfil Creek, while bank erosion is likely a dominant source of TSS. The results of this study can serve as the basis for future adaptive management experiments that seek to improve water quality in Innisfil Creek and beyond.
\end{abstract}




\section{Acknowledgements}

I would like to thank my supervisors, Dr. Claire Oswald and Dr. Stephanie Melles, as well as Dr. Chris Wellen and Dr. David Atkinson for their support throughout this process. This project would not be possible without field support from: Felix Chan, Nikolas Dellic, Jelena Grbic, Wai Lam and Kayla Wong. In addition, I would like to thank lan Ockenden for providing valuable input on this project.

I would like to thank my friends: Malik Haynes, Phillip Bowen, Stacey Foh, Renacin Matadeen, Wai Lam and Kayla Wong for all the moral support. I would especially like to thank my older brother and dad for feeding me and for driving me to the bus station. Most importantly, I would like to dedicate this thesis to my mother, who showed me nothing but love and support through the toughest times.

This project was made possible by the financial support provided by Environment and Climate Change Canada, and Ryerson University. 


\section{Table of Contents}

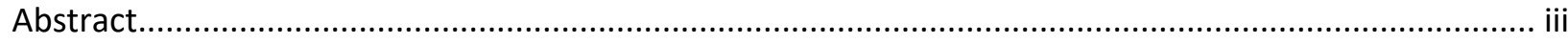

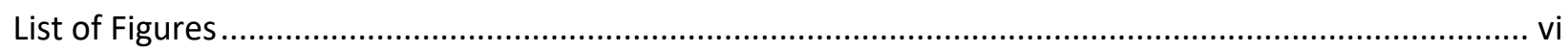

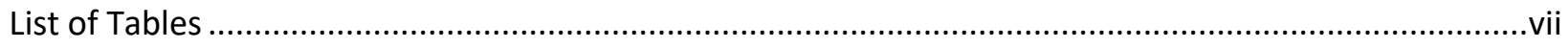

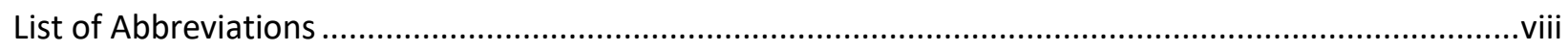

1. Introduction and Research Objectives..................................................................................... 1

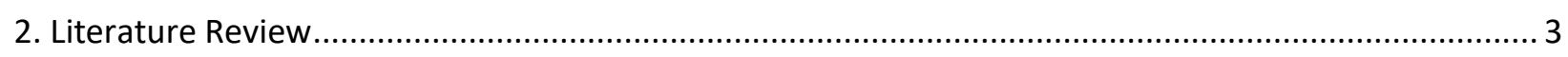

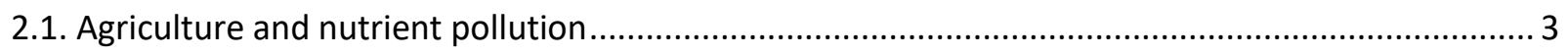

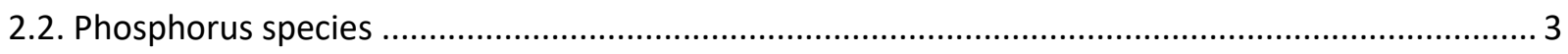

2.3. Phosphorus transport pathways in agricultural catchments..................................................... 4

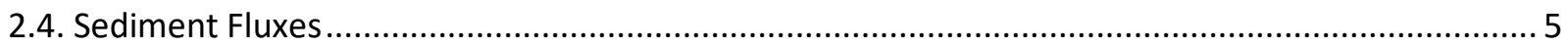

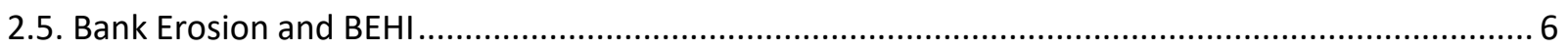

2.6. Riparian buffers for management of agricultural catchments .................................................. 6

2.7. Statistical approaches for examining relationships between catchment characteristics and water

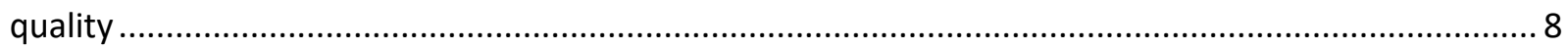

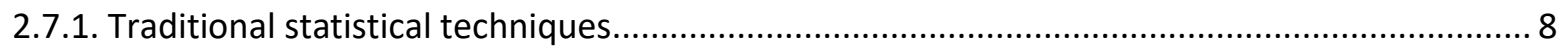

2.7.2. Partial least squares regression ..................................................................................... 9

3. Influence of catchment and stream characteristics on suspended solids and phosphorus concentrations across an agriculturally intensive watershed in southern Ontario ................................ 10

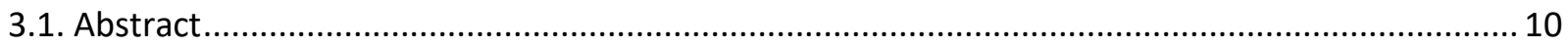

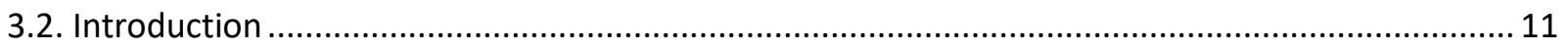

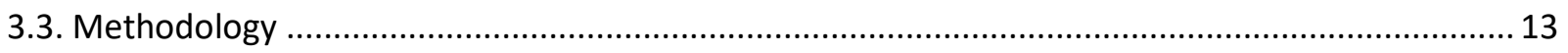

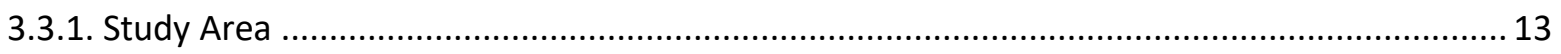

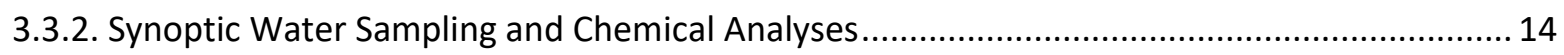

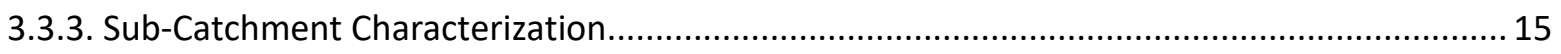

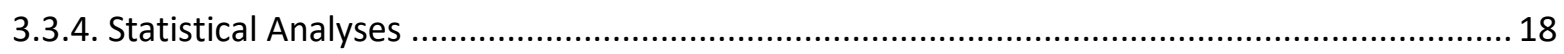

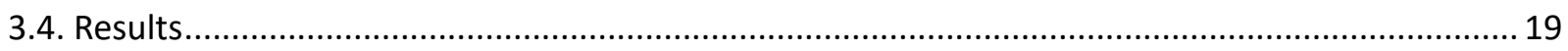

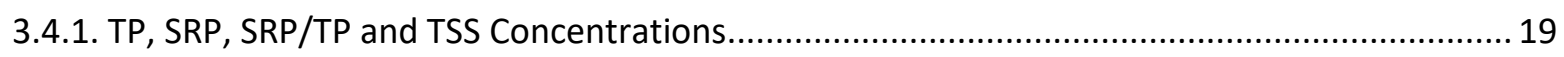

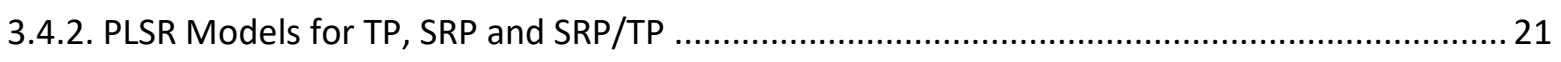

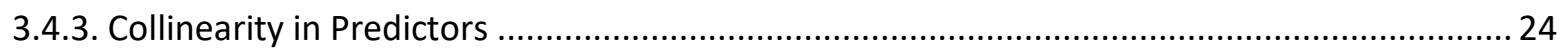

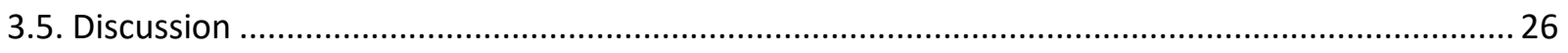

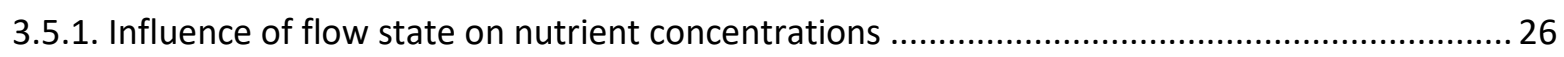

3.5.2. Influence of land use / land cover on nutrient and TSS concentrations ................................. 27

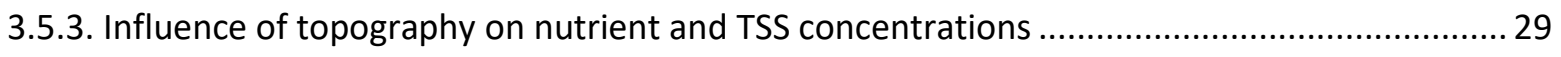

3.5.4. Influence of hydrologic soil groups on nutrient and TSS concentrations................................ 29

3.5.5. Influence of stream characteristics on nutrient and TSS concentrations ............................... 30

3.5.6. Influence of anthropogenic modifications on nutrient and TSS concentrations .................... 30

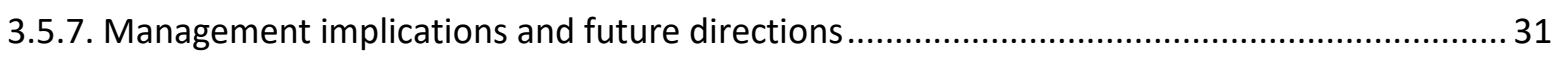

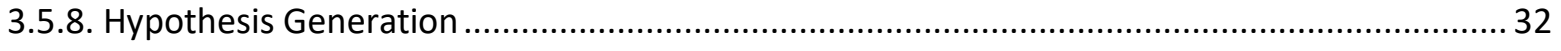

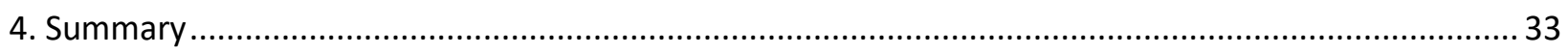

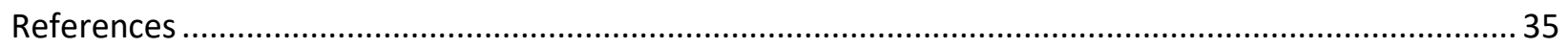




\section{List of Figures}

Figure 1. Maps of the Innisfil Creek watershed showing (a) land cover distribution and (b) synoptic sampling sites and their corresponding catchments. The location of Innisfil Creek within the Nottawasaga River watershed is shown on the inset. Panel a. Note that only stream orders 3 and higher are shown in panel b.

Figure 2. Annual flow duration curves (2010-2017) with the 2016/17 synoptic surveys overlaid (note that survey symbols represent flow condition classification).

Figure 3. Boxplots summarizing: a) TP $\left(\mathrm{mgL}^{-1}\right)$, b) SRP $\left(\mathrm{mgL}^{-1}\right)$, c) SRP/TP, and d) TSS $\left(\mathrm{mgL}^{-1}\right)$ concentrations under baseflow and stormflow conditions at each synoptic survey site over the study period. Line represents the median, upper and lower hinges correspond to the first and third quartiles and whiskers extend from hinges to $1.5 *$ interquartile range. Values in brackets at top of panel represent outliers that are not displayed. Asterisks beside site labels on x-axes indicate significant difference between baseflow and stormflow concentrations $(p<0.05)$ for each site via Mann-WhitneyWilcoxon test

Figure 4. The PLSR results (VIP values [bars] and regression coefficients [bar colour]) for component 1 of the baseflow and stormflow: (a) TP, (b) SRP, (c) SRP/TP, and (d) TSS models.

Figure 5. PCA loading plot for all 30 predictors. Principal component 1 (PC1) and principal component 2 (PC2) displayed 


\section{List of Tables}

Table 1. Description and abbreviation for all land use / land cover, topography, soil, stream characteristics, and anthropogenic modifications predictor variables examined in water quality

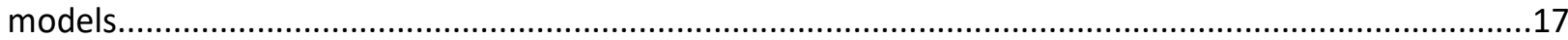

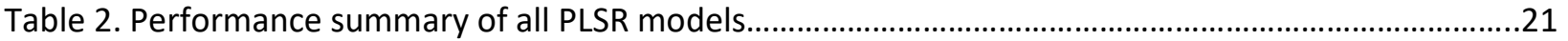

Table 3. Summary statistics of all predictor variables along with values at the outlet of Innisfil Creek

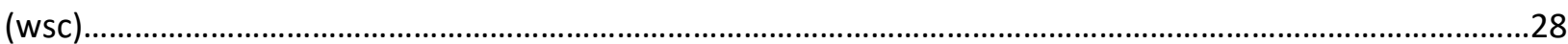




\section{List of Abbreviations}

$\begin{array}{ll}\text { BAP } & \text { Bioavailable Phosphorus } \\ \text { DOP } & \text { Dissolved Organic Phosphorus } \\ \text { DP } & \text { Dissolved Phosphorus } \\ \text { GWR } & \text { Geographically Weighted Regression } \\ \text { OLS } & \text { Ordinary Least Squares } \\ \text { PLSR } & \text { Partial Least Squares Regression } \\ \text { PP } & \text { Particulate Phosphorus } \\ \text { PCA } & \text { Principal Component Analysis } \\ \text { SRP/TP } & \text { Ratio of SRP to TP } \\ \text { SRP } & \text { Soluble Reactive Phosphorus } \\ \text { TDP } & \text { Total Dissolved Phosphorus } \\ \text { TP } & \text { Total Phosphorus } \\ \text { TSS } & \text { Total Suspended Solids } \\ \text { VIP } & \text { Variable Importance in Projection }\end{array}$




\section{Introduction and Research Objectives}

Anthropogenic eutrophication is a major threat to the health of freshwater ecosystems (Conley et al., 2009; Dupas et al., 2015a; Monteagudo et al., 2012). Excess nutrient inputs to water bodies can accelerate eutrophication, which can have devastating impacts on aquatic and human life (Dupas et al., 2015a; Kleinman et al., 2011). Algal blooms and increased growth of vascular plants can contribute to hypoxic conditions, leading to fish death and a decline in aquatic biodiversity (Kleinman et al., 2011; Monteagudo et al., 2012). Eutrophic lakes are often associated with cyanobacterial blooms, which occur during excessive phosphorus concentrations (Conley et al., 2009). Cyanobacteria can be particularly problematic because in addition to their contribution to hypoxic conditions in water bodies, they can be highly toxic to humans (Conley et al., 2009). Low order streams (Strahler order $<5$ ) can contribute large amounts of nutrient loads in aggregate to downstream systems; thus, they can have a large influence on the water quality of downstream water bodies (Dupas et al., 2015a). Agriculture is often associated with excessive phosphorus loads to surface waters (Kleinman et al., 2011; Verheyen et al., 2015). In watersheds dominated by agriculture, phosphorus from fertilizer applications is often transported from source areas into streams via surface and subsurface runoff (Fuchs et al., 2009; Stutter et al., 2008).

In addition to nutrient pollution, increased sediment concentrations through soil erosion and runoff can also cause impairment of river systems (Alberto et al., 2016; Russell et al., 2001). Although erosion is a natural process, conventional agricultural can increase the rate of erosion by 10 to 100 times (Montgomery, 2007) due to the removal of native vegetation, tillage and planting practices (Cerdà et al., 2009). Elevated sediment fluxes cause declines in the richness of benthic communities in lotic environments by reducing available habitat and food (Burdon et al., 2013; Larsen et al., 2009). Increased turbidity caused by elevated suspended sediment concentrations reduces light availability in streams, which can reduce the capacity for photosynthesis in submerged macrophytes (Garófano-Gómez et al., 2011; Pope and Odhiambo, 2014). Elevated sediment concentrations can also be deleterious to fish species, as sediment can smother fish eggs, interfere with respiration and reduce the abundance of prey (Tramblay et al., 2008).

Innisfil Creek, located in south-central Ontario and draining into the Nottawasaga River and eventually southeastern Georgian Bay, is dominated by intensive agricultural land use and has long suffered from impaired water quality. A previous study investigated the relative contribution of total suspended solids (TSS) and total phosphorus (TP) from multiple sub-catchments of the Nottawasaga River, including 
Innisfil Creek (Chow-Fraser, 2006). They found that TSS concentrations varied throughout the Nottawasaga River system and TSS and TP concentrations were highest at the outlet of Innisfil Creek during both a baseflow and a stormflow event. The study also found that TSS and TP concentrations increased substantially between the headwaters and outlet of Innisfil Creek and speculated that intensive agricultural activity in the middle of the watershed could be the source of the sediment. The authors concluded that further research is required to understand the landscape and hydrological drivers of elevated TP and TSS concentrations.

The influence of agricultural land cover, soil type, topography and hydrological characteristics on instream phosphorus concentrations across varying catchments has been studied extensively (Arheimer and Lide, 2000; Haygarth et al., 2005; Verheyen et al., 2015). Arheimer and Lide (2000) studied 35 catchments dominated by intensive agricultural activity and a found strong positive relationship between clay dominant soils and TP, particulate phosphorus (PP), and orthophosphate. Haygarth et al. (2005) studied the relationship between catchment area, phosphorus, and flow in six agriculturally intensive nested catchments of varying sizes. They found point sources (sewage) had a large influence on baseflow phosphorus, with dramatic flushing effects of PP during storm events. Verheyen et al. (2015) found dissolved phosphorus losses in arable catchments were significantly greater than in forested catchments, and they found that much of the TP losses occurred during storm events via overland flow. Very few studies have simultaneously examined the influence of agricultural land cover, soil type, topography and hydrological characteristics on phosphorus concentrations at sub-catchment and riparian scales for both baseflow and stormflow conditions in a nested catchment. To address this knowledge gap, our research focuses on understanding how flow state and catchment characteristics influence sub-catchment variability in phosphorous and sediment concentrations in a watershed dominated by agricultural land cover. Accordingly, our specific research objectives were to: 1) conduct a series of synoptic longitudinal surveys for stream TP, soluble reactive phosphorus (SRP) and TSS concentrations over a range of flow conditions; 2) characterize the topography, land cover/use, soils, stream morphology, and built environment for the sub-catchments draining each synoptic survey site; and 3) identify variables that best explain the spatial variability of in-stream TP, SRP, SRP/TP and TSS concentrations during baseflow and stormflow. The results of this study will assist in understanding the relationship between a large set of catchment characteristics and nutrient concentrations. This information will help determine best management practices needed to improve water quality in Innisfil 
Creek. Furthermore, the results of this study can assist in hypothesis generation for future experiments designed to identify specific catchment controls on nutrient concentrations.

\section{Literature Review}

\subsection{Agriculture and nutrient pollution}

The problem with elevated nutrients fluxes in freshwater environments is well documented. Elevated P and $\mathrm{N}$ levels can lead to eutrophication leading to oxygen depletion and animal kills (Dupas et al., 2015a; Kleinman et al., 2011). Catchments with high agricultural land use are of concern because phosphorus and nitrogen concentrations tend to increase in streams draining agricultural land (Bernot et al., 2006; Munn et al., 2010). Although highly urbanized catchments have many point sources of nutrient pollution (e.g., wastewater and septic), agricultural catchments are usually dominated by non-point source nutrient pollution (Monteagudo et al., 2012). Phosphorus, nitrogen and carbon all play a role in eutrophication, yet more focus is placed on phosphorus due to the difficulty in controlling natural exchange of nitrogen and carbon between the atmosphere and water (Sharpley and Wang, 2014). In addition, phosphorus is generally a limiting nutrient in freshwater systems and excess phosphorus loads are cited as one of the primary causes for freshwater eutrophication (King et al., 2015; Schindler et al., 2008). Thus, reducing phosphorus loads is crucial for controlling freshwater eutrophication.

\subsection{Phosphorus species}

Because TP is a poor predictor of bioavailable phosphorus (BAP), which controls eutrophication (Dupas et al., 2015b), it is rarely used as the sole metric for phosphorus pollution (McDowell and Wilcock, 2004). Phosphorus can be divided into two general categories, PP and dissolved phosphorus (DP) (Ellison and Brett, 2006; Spivakov et al., 1999). Dissolved phosphorus can be further subdivided into SRP, dissolved organic phosphorus (DOP) and dissolved acid-hydrolysable phosphorus (Spivakov et al., 1999). Soluble reactive phosphorus is often used in studies on nutrient pollution because it is readily bioavailable for assimilation by organisms (Spivakov et al., 1999; Zhang et al., 2016). Particulate phosphorus can be divided into organic and inorganic categories (Labry et al., 2013). Inorganic phosphorus is generally found adsorbed to particles but also exists as intracellular storage (Labry et al., 2013; Wang and Li, 2010; Yoshimura et al., 2007). 


\subsection{Phosphorus transport pathways in agricultural catchments}

Agriculture is often associated with excessive phosphorus loads to surface waters (Kleinman et al., 2011; Verheyen et al., 2015). In watersheds dominated by agriculture, phosphorus from fertilizer and manure applications is often transported from source areas into streams via surface and subsurface runoff (Fuchs et al., 2009; Stutter et al., 2008). Although significant amounts of TDP and PP can be transported through subsurface flows (Algoazany et al., 2007; Fuchs et al., 2009; Kronvang et al., 1997; Mellander et al., 2015), PP inputs are largely caused by surface runoff and stream bank erosion (Doody et al., 2006; Stutter et al., 2008). According to Lu et al. (2015), phosphorus loads typically originate from soil erosion in agricultural fields, but bank erosion is a primary source in lowland areas.

Precipitation events and changes in streamflow can create large fluctuations in phosphorus concentrations. If rain falls shortly after fertilizer application, this sequence of events can lead to the mobilization of large quantities of P (Kleinman et al., 2011; Preedy et al., 2001; Stutter et al., 2008). Multiple studies demonstrate an increase in TP and PP during storm flows (Ellison and Brett, 2006; Haygarth et al., 2005; Kronvang et al., 1997; Stutter et al., 2008). Kronvang et al. (1997) found the majority of PP and sediment input in a Danish catchment occur through bank erosion during storm events. Ellison and Brett (2006) saw an increase in PP, TP, and BAP concentrations by an average of $614 \%, 200 \%$ and $72 \%$, respectively. Haygarth et al. (2005) found point sources to be a major source of phosphorus during base flow, but during storm flow the authors saw a much greater concentration of phosphorus with negligible influence from point sources. At least one study has shown TP, PP, and SRP concentrations decrease with increasing flow due to dilution (Doody et al., 2006).

Traditionally, overland flow is typically seen as the dominant transport mechanism for $\mathrm{P}$ in agricultural catchments (Gentry et al., 2007; Verheyen et al., 2015). However, artificial drainage systems (e.g., tile drainage) can also serve as a major hydrological pathway for subsurface phosphorus transport in catchments with high soil phosphorus and low phosphorus sorption capacity (Dupas et al., 2015b; Gentry et al., 2007; Sims et al., 1998). Surface ditches and subsurface tile drains play a vital role in draining excess water in farm fields, which can improve crop yield. A large proportion of streamflow in agriculturally intensive catchments in United States (US) and Canada can be attributed to tile drains 
(King et al., 2015). Macrae et al. (2007) found that $42 \%$ of annual basin discharge originates from tile drains in a first order catchment located in Ontario, Canada. Studies by: King et al., 2014; Schilling et al., 2019; and Xue et al., 2010 found that tile drains account for $46-86 \%$ of streamflow in US catchments. In addition to contributing to a major source of streamflow, tile drains can be a source of phosphorus.

Sediments can also play a role in transporting pesticides, heavy metals, and nutrients such as phosphorus (Ding et al., 2010; Janes et al., 2018; Kronvang et al., 1997; Sanchez et al., 2015; Tramblay et al., 2008). These contaminants can bind to sediments via sorption and move downstream. Particulate phosphorous is less bioavailable than TDP because the bioavailability of PP is controlled by a variety of chemical processes and can be influenced by physical variables such as particle size (Ellison and Brett, 2006; Zhu et al., 2013). Studies show that the bioavailability of PP is higher in finer particles, such as clay, than coarse particles like sand (Reynolds and Davies, 2001; Yao et al., 2016). Agricultural streams display high variability in bioavailable PP, ranging from less than $5 \%$ to $69 \%$, depending on the type of agriculture (Ellison and Brett, 2006).

\subsection{Sediment Fluxes}

In addition to nutrient pollution, erosion and runoff can cause increased sediment concentrations through leading to further impairment of river systems (Alberto et al., 2016; Russell et al., 2001). Elevated sediment fluxes cause decline in richness of benthic communities in lotic environments (Burdon et al., 2013; Larsen et al., 2009). For example, Burdon et al. (2013) conducted extensive surveys of agricultural streams and found that an increase in sediment inputs from agricultural activity was negatively correlated with the diversity of pollution sensitive invertebrate species. The authors used structural equation modelling to determine that fine sediment covering the stream bed, was a major contributor to the loss of invertebrate diversity due to habitat loss. Elevated sediment concentrations can also be deleterious to fish species, as sediment can smother fish eggs, interfere with respiration and reduce the abundance of prey (Tramblay et al., 2008). Increased sediment can reduce diversity of pollution sensitive species, and correspondingly, a reduction in flow along with the addition of fine sediment is associated with an increase in abundance of pollution tolerant species due to additional habitat availability (Lenat et al., 1981; Matthaei et al., 2010). The increased turbidity caused by elevated suspended solids concentrations reduces light availability in streams, which can reduce the capacity for photosynthesis in submerged macrophytes (Garófano-Gómez et al., 2011; Pope and Odhiambo, 2014). 


\subsection{Bank Erosion and BEHI}

Bank erosion is often cited as a major source of sediments and nutrients in lotic systems (Allmanová and Jakubis, 2016; Kronvang et al., 1997; Lammers et al., 2017; McMillan et al., 2018). Stream bank erosion can be caused by two major factors: hydraulic/gravitation forces and bank erodibility potential (Janes et al., 2018; Prosdocimi et al., 2015; Rosgen, 2001). Erosion by hydraulic forces is often a product of flow mechanics, whereas erodibility is often determined by a variety of factors, including; bank slope, vegetation cover, and sinuosity (Janes et al., 2018; McMillan et al., 2018; Rosgen, 2001). Sinuosity can lead to increased bank erosion due to increased shear stress on outer banks (McMillan et al., 2018). However, riparian vegetation can reduce bank erosion by improving bank stability (Naiman and and Décamps, 1997) and it can reduce agricultural runoff and sediment inputs to streams (Burrell et al., 2013; Pollen and Simon, 2005). Riparian buffers are often implemented by managers as a best management strategy in order to reduce erosion (Rios and Bailey, 2006; Zhang et al., 2017).

The need to integrate streambank erosion processes in erosion prediction models led to the creation of the Bank Erosion Hazard Index (BEHI) (Rosgen, 2001). According to Rosgen (2001), BEHI uses key streambank characteristics, which indicate potential for erosion. The streambank characteristics included in the BEHI are: the ratio of bank height/bank full height; the ratio of rooting depth/bank height; root density; bank slope; percent surface area protected; bank materials; and soil stratification. $\mathrm{BEHI}$ is effective at predicting the extent of stream bank erosion, and at identifying stream banks vulnerable to erosion (Allmanová and Jakubis, 2016; Kwan and Swanson, 2014).

\subsection{Riparian buffers for management of agricultural catchments}

No universal definition of a riparian area exists but they can generally be described as transitional zones between land and freshwater ecosystems, characterized by unique biotic, hydrologic, and soil conditions (Sosa et al., 2018; Verry et al., 2005). Riparian areas are terrestrial areas, which are directly influenced by aquatic ecosystems (Verry et al., 2005). They are extremely diverse and complex, and they can perform a variety of important ecological functions, such as reducing agricultural runoff, promoting nutrient cycling, flood control, and reducing bank erosion (Naiman and and Décamps, 1997; Naiman et al., 1993; Rios and Bailey, 2006; Teufl et al., 2013). Riparian vegetation can influence aquatic systems by altering light availability and temperature: for example, a lack of riparian forest cover will increase light availability, which can lead to an increase in autotrophic production, potentially leading to 
eutrophication (Burrell et al., 2013; Naiman and and Décamps, 1997). Riparian vegetation can also provide bank stability, which reduces both sediment input to the stream and turbidity (Burrell et al., 2013; Pollen and Simon, 2005). Non-vegetated bank slopes tend to be unstable compared to their vegetated counterparts, with bank erosion approximately 30 times more prevalent in non-vegetated areas relative to vegetated areas (Naiman and Décamps, 1997).

The crucial role played by riparian vegetation has led managers and planners to implement riparian buffers as a best management strategy to reduce nutrient and sediment inputs (Rios and Bailey, 2006; Zhang et al., 2017). A riparian buffer is typically a three-zone system; the unmanaged zone adjacent to the stream, an upslope managed woody slope, bordered by a third zone consisting of grasses designed to reduce runoff (Schultz et al., 2004; Zhang et al., 2017). According to Schultz et al. (2004) a riparian forest buffer has 3 major objectives. The first is the removal of pollutants such as nutrients, organic matter and pesticides from surface runoff through processes such as deposition, absorption, plant uptake and denitrification. The second objective is to create shade to lower stream temperature. The last objective is to provide detritus and other debris for aquatic organisms. Riparian buffers can play a major role in limiting soil loss in agroecosystems (Schultz et al., 2004). Woody structures in the buffer can reduce erosion by acting as a windshield, while plant root systems can increase infiltration and trap sediments (Lovell and Sullivan, 2006). The continuity and width of riparian buffers can determine their effectiveness. Continuity in buffers is key to maintaining biodiversity in riparian ecotones. A continuous riparian buffer can serve as a transportation corridor for a variety of species (Naiman et al., 1993). Some studies suggest that discontinuities in buffers can limit their effectiveness to retain sediment (Bhattarai et al., 2009; Teufl et al., 2013). Riparian buffer widths can be crucial to their effectiveness in reducing nutrient and sediment inputs to streams. No clear consensus exists on the minimum effective width of a buffer. Zhang et al. (2016) found that a 10 to $30 \mathrm{~m}$ buffer on each side of the stream is critical in reducing nutrient and sediment pollution. Lee et al. (2003) found that a $16.3 \mathrm{~m}$ woody/switch grass buffer is effective at removing over $90 \%$ of sediment before it enters the stream; whereas Environment Canada (2013) recommends a minimum forest buffer of $30 \mathrm{~m}$ on each side of a stream to maintain a healthy stream. 


\subsection{Statistical approaches for examining relationships between catchment characteristics and water quality}

\subsubsection{Traditional statistical techniques}

Spatial and aspatial statistical techniques can be useful in identifying relationships between landscape characteristics and water quality. Aspatial techniques such as Spearman's correlation and stepwise multiple regression were successfully used to study the relationships between $\mathrm{P}$ and land cover at different scales (Arheimer and Lide, 2000; Banner et al., 2009; Tromboni and Dodds, 2017; Zampella et al., 2007). Tromboni and Dodds (2017) used Spearman's rank correlation, stepwise multiple linear regression, and breakpoint regression to study the relationship between nutrients and land use across 35 watersheds in Brazil. The authors examined these relationships at both the catchment scale and a riparian scale ( $30 \mathrm{~m}$ buffer). The correlation results showed urban land cover at the watershed scale had the strongest positive relationship with nutrient concentration. Breakpoint regression was used to study threshold responses between flow and nutrient concentration. Banner et al. (2009) studied the relationship between land cover (catchment and riparian scale), stream discharge, and TP (loads and concentrations). Percent of time a flow was exceeded and TP concentrations were paired and analyzed through breakpoint regression to identify a threshold response. All flows with values less than the discharge breakpoint, which was determined from the breakpoint regression, were assigned the median TP concentration during baseflow for that site. Significant discharge/concentration relationships were used to model daily TP loads. Arheimer and Lide (2000) used Kendall's tau and stepwise multiple linear regression to study the relationship between nutrient concentrations and a variety of explanatory variables, including; land use, slope, and soil type for 30 sample sites with 5 additional sites reserved for model validation. The authors concluded organic nitrogen and PP could not be predicted by linear regression.

Zampella et al. (2007) used multiple linear regression and ANOVA tests to study the relationship between land use and water quality. The authors used 25 sample sites with a variety of water quality data, including TP, collected over a three-year period at base flow conditions. Median concentration for each water quality variable at each site was selected for analysis. The authors combined percent of upland agriculture and percent urban land into four categories based on the percent altered land use in each watershed $(<10 \%, 10-19 \%, 40-49 \%$, and $>50 \%)$, and they conducted an ANOVA test on each water quality variable based on the land category. The authors conducted a forward stepwise multiple 
regression to determine the relationship between land use variables (basin-wide and distance weighted) and water quality. The regression model with land use was used to predict water quality at model validation sites. Regression results showed a strong relationship between altered land use and a variety of water quality variables.

\subsubsection{Partial least squares regression}

Partial least squares regression (PLSR) combines aspects of principal component analysis (PCA) and multiple linear regression. The goal of PLSR is to predict $Y$ (the matrix of dependent variables and observations) from X (the matrix of independent variables and observations) (Abdi, 2010; Carrascal et al., 2018; Ferreira et al., 2017). In scenarios where the number of observations is less than the number of predictor variables, and the dataset is highly correlated (often described as the 'small $\mathrm{n}$ large $\mathrm{p}$ ' problem), PLSR is especially effective (Abdi, 2010; Carrascal et al., 2018; Mehmood et al., 2012). In these scenarios, multiple regression is not possible due to the large number of predictors relative to the number of observations (Abdi, 2010). Alternative approaches can address this by selecting variables through techniques like stepwise linear regression or through a PCA of the $X$ matrix followed by linear regression (Abdi and Williams, 2010; Ferreira et al., 2017). The problem with conducting a PCA followed by a regression as opposed to PLSR is that an optimal set of predictor variables are not selected in the PCA (Ferreira et al., 2017). A PCA creates components using the $X$ matrix that best describe variation in $X$, which does not guarantee that the components will optimally predict $Y$ (Ferreira et al., 2017). A simultaneous decomposition of $\mathrm{X}$ and $\mathrm{Y}$ is performed by PLSR to create components that explain as much variation between $X$ and $Y$ as possible (Abdi \& Williams, 2010; Carrascal et al., 2018; Ferreira et al., 2017).

Variable selection in PLSR is important because redundant variables can lead to low statistical significance (Martínez et al., 2017; Mehmood et al., 2012; Shi et al., 2013). According to Mehmood et al. (2012) there are 3 general approaches for variable selection in PLSR: the filter method, the wrapper method, and the embedded method. The filter method works by first running the PLSR with all predictor variables, where a threshold is set to determine which variables will be included in the model. The threshold can be placed on the loading weights, regression coefficients, or the variable importance in projection (VIP) values to identify the important variables. Variables with high VIP values are more important/relevant in explaining the dependent variable (Shi et al., 2013). Variable selection in the filter method highly depends on the threshold value chosen by the user. The wrapper method as described by 
Mehmood et al. (2012) uses a filter method with a supervised learning approach. Wrapper methods extract a subset of variables and fit a model to the subset to evaluate it. The algorithms can either be random (subset selected randomly) or deterministic (subset not selected randomly) (Mehmood et al., 2012; Saeys et al., 2007). Genetic algorithms combined with PLS regression (GA-PLS), uninformative variable elimination in PLS (UVE-PLS), backward variable elimination PLS (BE-PLS), and sub-window permutation analysis coupled with PLS (SWPA-PLS) are a few of the wrapper methods described by Mehmood et al. (2012). Embedded methods are similar to wrapper methods, but unlike wrapper methods, they are embedded in the PLS model itself and are thus less computationally expensive than wrapper methods (Mehmood et al., 2012; Saeys et al., 2007).

\section{Influence of catchment and stream characteristics on suspended solids and phosphorus concentrations across an agriculturally intensive watershed in southern Ontario}

\subsection{Abstract}

Excess phosphorus inputs into freshwater systems from agricultural activities can accelerate eutrophication, which can have devastating impacts on aquatic and human life. A variety of landscape and hydrological characteristics can influence nutrient concentrations in freshwater systems. The combined influence of these characteristics on nutrient concentrations is still poorly understood. The overall objective of this study is to determine the influence of landscape and hydrological characteristics on sub-catchment variability of total phosphorus (TP), soluble reactive phosphorus (SRP), the ratio of SRP and TP (SRP/TP), and total suspended solids (TSS). Fourteen longitudinal synoptic surveys were conducted for 13 sampling sites over a variety of flow conditions in the Innisfil Creek watershed located in southern Ontario. The surveys were split into baseflow and stormflow and partial least squares regression (PLSR) was used to analyze the relationship between watershed and hydrological characteristics, median concentrations of phosphorus, and TSS. All stormflow models had a better predictive performance than the baseflow models. The stormflow SRP, SRP/TP and TSS models had 'good' predictive performance (goodness of prediction $>0.5$ ). According to the variable importance in projection (VIP) statistic, hydrologic soil groups and density of constructed drain density had the greatest influence on stormflow SRP. Hydrologic soil groups, winter wheat, and constructed drain 
density had the largest influence in the stormflow SRP/TP model, while bank erosion hazard index, sinuosity, and slope had the largest influence in the stormflow TSS model. The PLSR models indicate that buried tile drainage might be a major source of SRP in Innisfil Creek, while bank erosion is likely a dominant source of TSS. The results of this study can serve as the basis for future adaptive management experiments that seek to improve water quality in Innisfil Creek and beyond.

\subsection{Introduction}

Anthropogenic eutrophication is a major threat to the health of freshwater ecosystems (Conley et al., 2009; Dupas et al., 2015a; Monteagudo et al., 2012). Excess nutrient inputs to water bodies can accelerate eutrophication, which can have devastating impacts on aquatic and human life (Dupas et al., 2015a; Kleinman et al., 2011). Algal blooms and increased growth of vascular plants can contribute to hypoxic conditions when they decay, leading to fish death and a decline in aquatic biodiversity (Kleinman et al., 2011; Monteagudo et al., 2012). Eutrophic lakes are characterized by imbalanced nitrogen to phosphorus ratios with higher phosphorus, which can often lead to cyanobacterial blooms (Conley et al., 2009). Cyanobacteria can be particularly problematic because in addition to their contribution to hypoxic conditions in water bodies, they can be highly toxic to humans (Conley et al., 2009).

Agriculture is often associated with excessive phosphorus loads to surface waters (Kleinman et al., 2011; Verheyen et al., 2015). In watersheds dominated by agriculture, phosphorus from fertilizer applications is often transported from source areas into streams via surface and subsurface runoff (Arheimer and Lide, 2000; Fuchs et al., 2009; Sharpley et al., 2008; Stutter et al., 2008). Artificial drainage systems (e.g. tile drainage) also serve as major hydrological pathways for excess phosphorus transport in agricultural watersheds (Dupas et al., 2015b; Gentry et al., 2007). However, overland flow is typically the dominant transport mechanism for phosphorus in agricultural watersheds (Gentry et al., 2007; Verheyen et al., 2015). Total phosphorus (TP) is rarely used as the only measure for phosphorus pollution because TP is a poor predictor of bioavailable phosphorus (BAP) (McDowell and Wilcock, 2004), which controls eutrophication (Dupas et al., 2015b). Soluble reactive phosphorus is an especially important phosphorus species because it is readily bioavailable for assimilation by organisms (Spivakov et al., 1999; Zhang et al., 2016). 
In addition to nutrient pollution, increased sediment concentrations through soil erosion and runoff can cause impairment of river systems (Alberto et al., 2016; Russell et al., 2001). Although erosion is a natural process, conventional agricultural can increase the rate of erosion by 10 to 100 times rates found under native vegetation cover (Montgomery, 2007). This is due to tillage, planting practices, and the removal of native vegetation (Cerdà et al., 2009). Elevated sediment fluxes cause declines in richness of benthic communities in lotic environments by reducing available habitat and food (Burdon et al., 2013; Larsen et al., 2009). Increased turbidity caused by elevated suspended sediment concentrations reduces light availability in streams, which can reduce the capacity for photosynthesis in submerged macrophytes (Garófano-Gómez et al., 2011; Pope and Odhiambo, 2014). Elevated sediment concentrations can also be deleterious to fish species, as sediment can smother fish eggs, interfere with respiration, and reduce the abundance of prey (Tramblay et al., 2008). A variety of studies have found a relationship between total suspended solids (TSS) and particulate phosphorus (PP) (Ellison and Brett, 2006; Haygarth et al., 2005; Pacini and Gächter, 1999; Poirier et al., 2011; Udeigwe et al., 2007). Poirier et al. (2011) found a strong positive relationship between TSS and PP, while Ellison and Brett (2006) found a weak positive relationship between TSS and PP. An experimental study by Udeigwe et al. (2007) found a strong relationship between runoff PP and TSS. Surprisingly, Fulweiler and Nixon (2005) found no relationship between TSS and PP, the authors argued that this could be explained by the resuspension of nutrient poor particulate matter from the streambed during stormflow conditions.

Streambank erosion is often cited as a major source of sediments and nutrients in lotic systems (Allmanová and Jakubis, 2016; Kronvang et al., 1997; Lammers et al., 2017; McMillan et al., 2018). Stream bank erosion can be caused by two major factors: hydraulic/gravitation forces and bank erodibility potential (Janes et al., 2018; Prosdocimi et al., 2015; Rosgen, 2001). Erosion by hydraulic forces is often a product of flow mechanics, whereas erodibility is often determined by a variety of factors, including; bank slope, vegetation cover, and sinuosity (Janes et al., 2018; McMillan et al., 2018; Rosgen, 2001). However, riparian vegetation can reduce bank erosion by improving bank stability (Naiman and and Décamps, 1997), and vegetated riparian buffers can reduce agricultural runoff and sediment inputs to streams (Burrell et al., 2013; Pollen and Simon, 2005). Indeed, riparian buffers are often recommended as a best management strategy to reduce sediment loading and erosion (Rios and Bailey, 2006; Zhang et al., 2017).

The influence of agricultural land cover, soil type, topography and hydrological characteristics on instream phosphorus concentrations across catchments has been studied extensively (Arheimer and 
Lide, 2000; Haygarth et al., 2005; Verheyen et al., 2015). Arheimer and Lide (2000) studied 35 catchments dominated by intensive agricultural activity and a found strong positive relationship between clay dominant soils and total phosphorus (TP), particulate phosphorus (PP), and orthophosphate. Haygarth et al. (2005) studied the relationship between catchment area, phosphorus and flow in six agriculturally intensive nested catchments of varying sizes. They found point sources (sewage) had a large influence on baseflow phosphorus, with dramatic flushing effects of PP during storm events. Verheyen et al. (2015) found dissolved phosphorus losses in arable catchments were significantly greater than in forested catchments, and they found that much of the TP losses occurred during storm events via overland flow. Very few studies have simultaneously examined the influence of agricultural land cover, soil type, topography and hydrological characteristics on phosphorus concentrations at sub-catchment and riparian scales for both baseflow and stormflow conditions in a nested catchment. To address this knowledge gap, our research focuses on understanding how flow state and catchment characteristics influence sub-catchment variability in phosphorous and sediment concentrations in a watershed dominated by agricultural land cover. Accordingly, our specific research objectives were to: 1) conduct a series of synoptic longitudinal surveys for stream TP, SRP and TSS concentrations over a range of flow conditions; 2) characterize the topography, land cover/use, soils, stream morphology, and built environment for the sub-catchments draining each synoptic survey site; and 3) identify variables that best explain the spatial variability of in-stream TP, SRP, SRP/TP and TSS concentrations during baseflow and stormflow. The results of this study will assist in understanding the relationship between a large set of catchment characteristics and nutrient concentrations. This information will help determine best management practices needed to improve water quality in Innisfil Creek. Furthermore, the results of this study can assist in hypothesis generation for future experiments designed to identify specific catchment controls on nutrient concentrations.

\subsection{Methodology}

\subsubsection{Study Area}

The $477.4 \mathrm{~km}^{2}$ Innisfil Creek subwatershed is located within the Nottawasaga River watershed in southern Ontario (inset Figure 1a). A large proportion of the land in Innisfil Creek's watershed is dominated by intensive agricultural crops such as sod, wheat, corn and soybeans. (Figure 1a). The lowlands of Innisfil Creek are primarily composed of sand-silt plains, whereas the highlands consist of 
Oak Ridges Moraines, Schomberg Clay Plains, and the sand-silt plains of the Simcoe uplands (Nottawasaga Valley Conservation Authority (NVCA), 2013). Innisfil Creek has an average temperature of $7.7^{\circ} \mathrm{C}$ and receives an average of $834.4 \mathrm{~mm}$ of annual precipitation; approximately $18 \%$ of the annual precipitation falls as snow during the winter months (October - April) (Environment Canada, 2018). According to the Nottawasaga Valley Conservation Authority (NVCA) (2013), Innisfil Creek's watershed has lower forest cover, higher surface water pollution, and lower wetland cover than the rest of the Nottawasaga watershed. Innisfil Creek has low benthic diversity and relatively high levels of phosphorus, TSS, and Escherichia coli (E. coli).

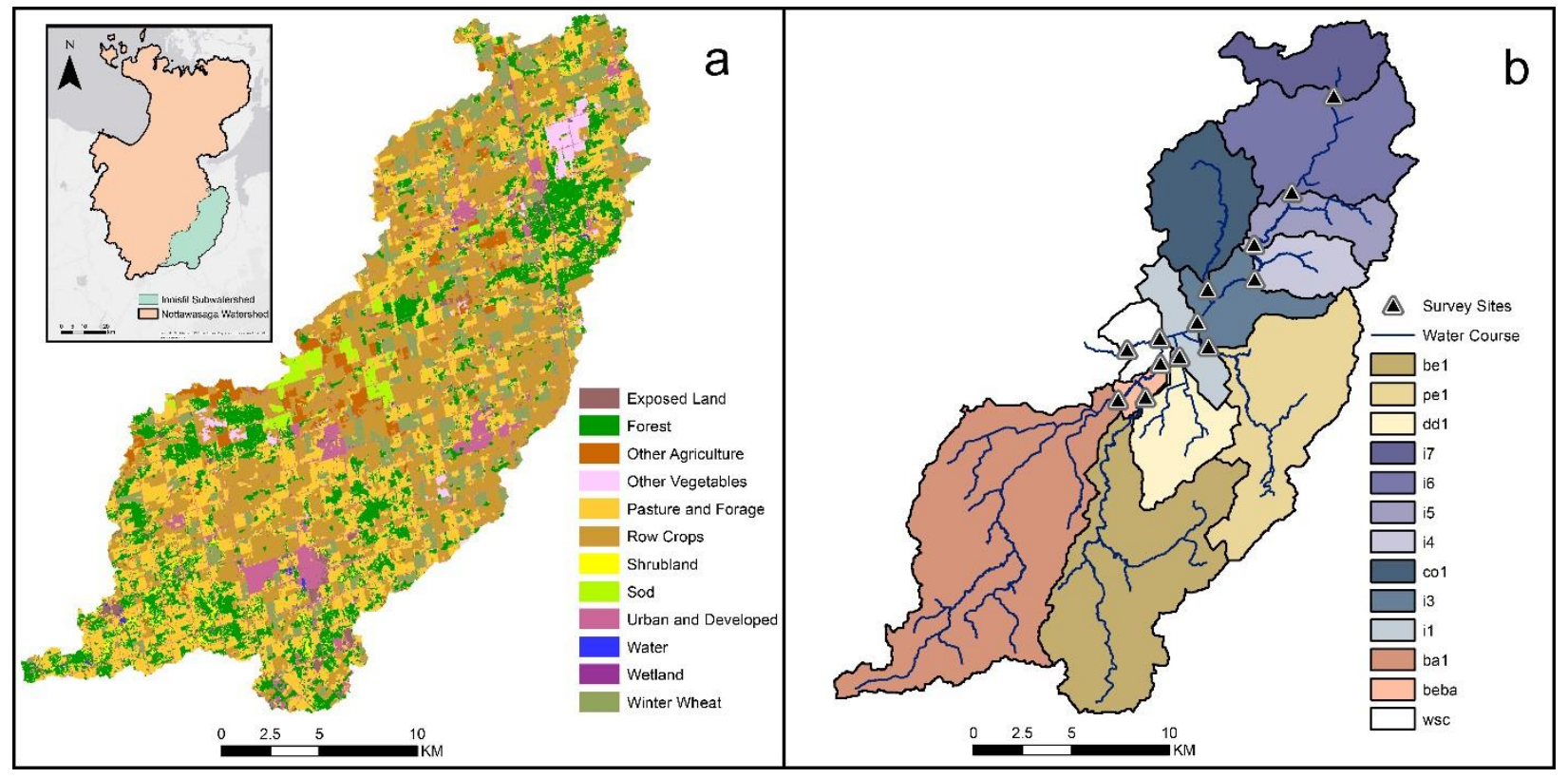

Figure 1. Maps of the Innisfil Creek watershed showing (a) land cover distribution and (b) synoptic sampling sites and their corresponding catchments. The location of Innisfil Creek within the Nottawasaga River watershed is shown on the inset. Panel a. Note that only stream orders 3 and higher are shown in panel $b$.

\subsubsection{Synoptic Water Sampling and Chemical Analyses}

Thirteen water sampling sites were selected along the main stem of Innisfil Creek (usually up and downstream of the confluence of major tributaries and municipal drainage ditches) and on major tributaries that flow into the main stem (Figure 1b). Fourteen synoptic water quality surveys were conducted over a range of flow conditions between November 2016 and October 2017 (Figure 2). Previous studies showed that P loads can vary between baseflow and stormflow conditions (e.g., Banner et al., 2009; Gentry et al., 2007; Janke et al., 2014). Accordingly, we classified our synoptic surveys into baseflow or stormflow conditions using the beta version of the HydRun toolbox for Matlab (Tang and 
Carey, 2017). Hydrun uses a hydrograph separation algorithm along with a smoothing filter to extract event flows in Matlab. A more detailed discussion of the "extractrunoffevent.m" function can be found in (Tang and Carey, 2017). After using HydRun, we were able to classify our 14 surveys into seven baseflow and seven stormflow surveys.

All TP and SRP samples were analyzed colorimetrically with the Bran Luebbe AA3 autosampler via EPA method 365.1 (O'Dell, 1993). Samples for TP were digested with acid persulfate in an autoclave. Samples for SRP were filtered through a $0.45 \mu \mathrm{m}$ filter before being analyzed. Samples for TSS were determined by filtering the sample through a $0.45 \mu \mathrm{m}$ filter and subtracting the filter weights before and after filtering. Detection limits for TP, SRP, and TSS were $0.01 \mathrm{mgL}^{-1}, 0.001 \mathrm{mgL}^{-1}$, and $0.1 \mathrm{mgL}^{-1}$ respectively.

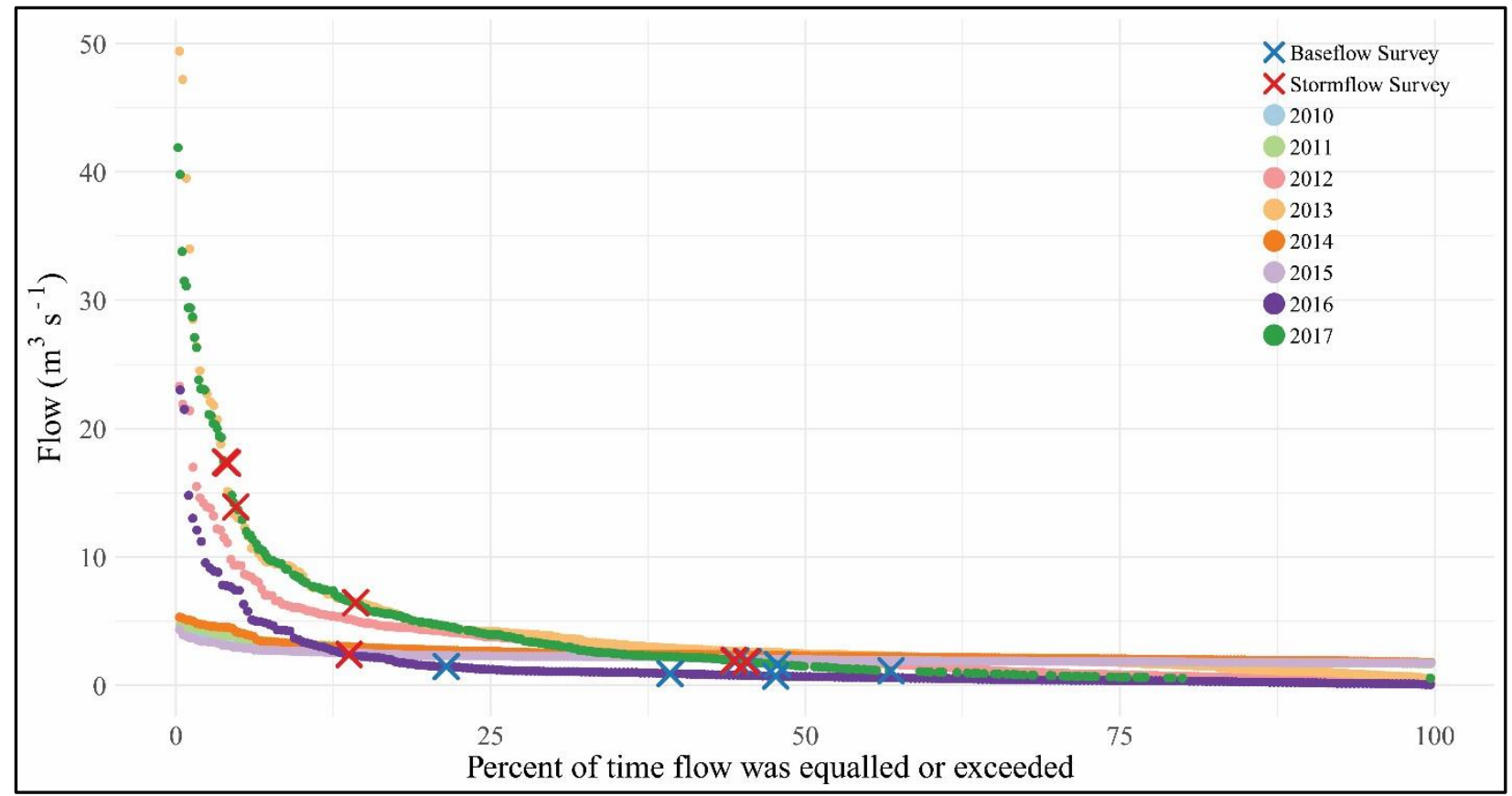

Figure 2. Annual flow duration curves (2010-2017) with the 2016/17 synoptic surveys overlaid (note that survey symbols represent flow condition classification).

\subsubsection{Sub-Catchment Characterization}

Watersheds were delineated for each site using the Ontario Flow Assessment Tool (OFAT II) (Ministry of Natural Resources and Forestry, 2017) at a 30-m resolution. The sub-catchment for each synoptic water survey point was characterized using 30 predictor variables, and each of these variables can be further grouped into land cover / land use, topography, soil, stream characteristics, and anthropogenic modifications for descriptive purposes (Table 1). Land cover variables were generated from the 2017 
Annual Crop Inventory (Agriculture and Agri-Food Canada, 2017). PCl Geomatica was used to conduct a supervised classification of Sentinel 2 imagery. The classified image was used to generate the riparian forest and field variables at a $10 \mathrm{~m}$ resolution. Hydrologic soil groups, tile drainage area, and constructed drains data were provided by Ontario Ministry of Agriculture, Food and Rural Affairs (OMAFRA, 2018, 2015a, 2015b). Hydrologic soil groups are texture-based classification of soils. Soils with fine texture (soil group D), have high levels of clay and a high runoff potential. Soils with coarse texture (hydrologic soil group A), have a large amount of sand and a low runoff potential.

A 2 m DEM was acquired from the South-Central Ontario Orthophotography Project (Ministry of Natural Resources and Forestry, 2015) which covered approximately 95\% of the Innisfil Creek subwatershed. A $10 \mathrm{~m}$ DEM was resampled to $2 \mathrm{~m}$ by dividing each cell into $2 \mathrm{~m}$ cells and this was mosaicked with the $2 \mathrm{~m}$ DEM to fill in the missing areas. The mosaicked DEM was used to generate elevation and slope variables.

Rosgen's bank erosion hazard index (BEHI) is an effective predictor of streambank erosion risk (Allmanová and Jakubis, 2016; Rosgen, 2001) that uses key streambank characteristics. BEHI can also be used to identify stream banks that are vulnerable to erosion (Allmanová and Jakubis, 2016; Kwan and Swanson, 2014). In August 2018, we conducted field surveys to measure BEHI (350 m upstream of each sample site). Streambank characteristics included in the BEHI are: ratio of bank height to bank full height; ratio of rooting depth to bank height; root density; bank slope; percent surface area protected; bank materials; and stratification (Rosgen, 2001).

Sinuosity can lead to increased bank erosion due to increased shear stress on outer banks (McMillan et al., 2018). Sinuosity was calculated as the ratio of stream length to straight-line distance for each stream segment. Stream segments were delineated by natural confluences, or sample site locations were used as start and endpoints of stream segments. Segment sinuosity was calculated using a user created toolkit for ArcMap (Dilts, 2015). Segment lines were converted to grid cells (30 m raster) in ArcMap, so that each pixel had a sinuosity value. The mean sinuosity value for all pixels within a sub-catchment was calculated. Field observations indicated that bridges may be a large source of suspended sediment in Innisfil Creek. Bridges were generated by intersecting the street network with the stream network to generate crossings. Estimates of mean sub-catchment sinuosity, elevation, slope variables, and number of bridges per km of stream were generated in ArcMap 10.6.1. 
Table 1. Description and abbreviation for all land use / land cover, topography, soil, stream characteristics, and anthropogenic modifications predictor variables examined in water quality models.

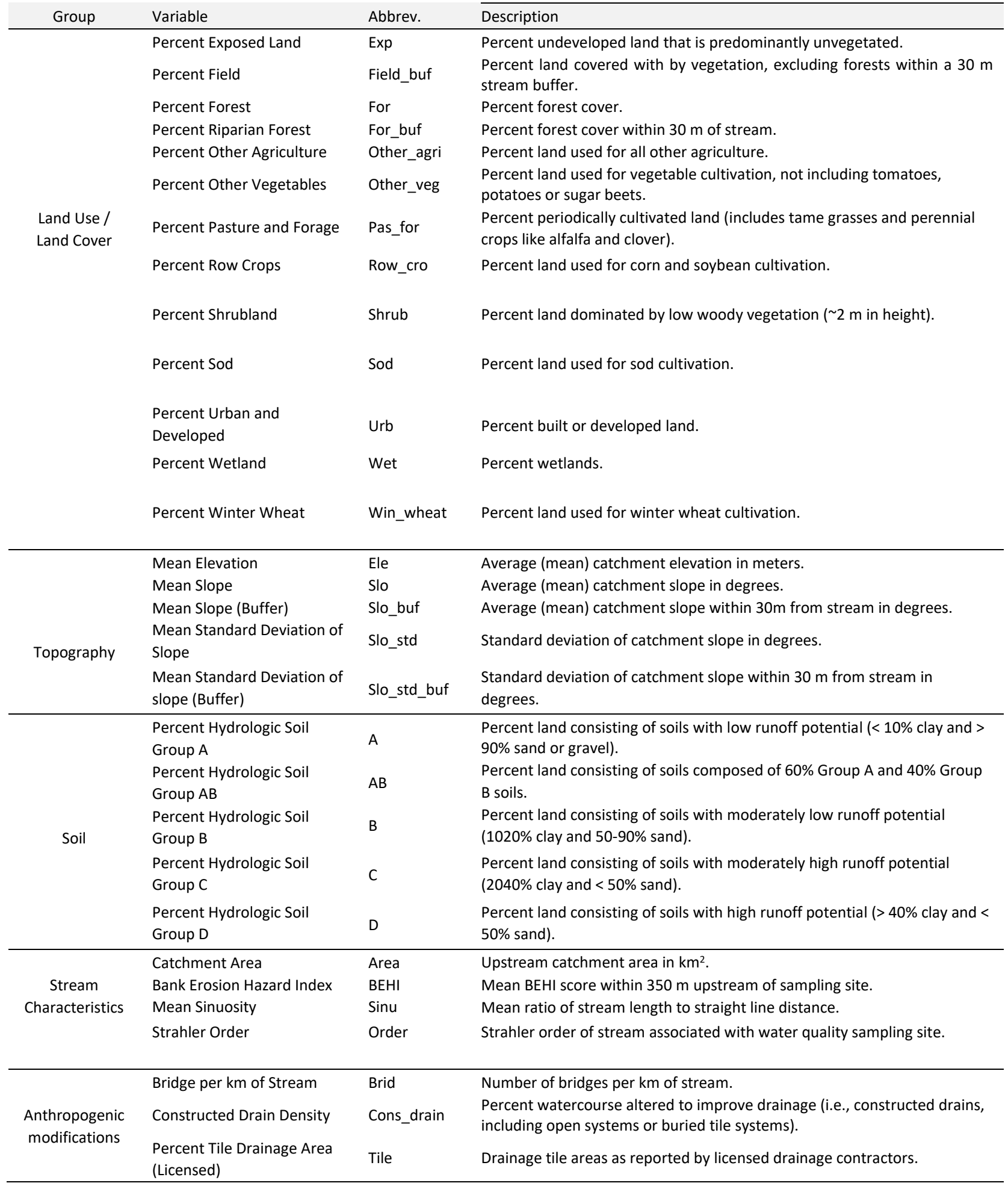




\subsubsection{Statistical Analyses}

To detect significant differences between baseflow and stormflow concentrations of TP, SRP, SRP/TP and TSS at each site, the Mann-Whitney-Wilcoxon test was conducted. A similar multiple comparison test to detect significant differences of concentrations between sampling sites could not be conducted due to the large number of sampling site combinations. The results of the Mann-Whitney-Wilcoxon test can provide some indication on the concentration discharge relationships in Innisfil Creek.

To examine the influence of landscape characteristics and hydrological conditions on phosphorus and suspended solids levels we used partial least squares regression (PLSR). This technique combines aspects of principal component analysis (PCA) and multiple linear regression to predict $Y$ (i.e., a matrix of dependent variables) from X (i.e., the matrix of independent variables) (Abdi, 2010; Carrascal et al., 2018; Mehmood et al., 2012). In scenarios where the number of observations is less than the number of predictor variables, and where the dataset is highly correlated - often described as the 'small $n$ large $p$ ' problem - PLSR is especially effective (Abdi, 2010; Carrascal et al., 2018; Mehmood et al., 2012). In these scenarios, multiple regression is not possible due to the large number of predictors relative to the number of observations, which leads to overfitting (Abdi, 2010). Alternative approaches can address this by selecting variables through techniques like stepwise linear regression or by using PCA on the X matrix followed by multiple linear regression (Abdi and Williams, 2010; Ferreira et al., 2017). The problem with conducting a PCA followed by regression, as opposed to PLSR, is that an optimal set of variables in relation to the dependent variable matrix is not selected by PCA (Ferreira et al., 2017). A PCA creates components using the $\mathrm{X}$ matrix that best describe variation in $\mathrm{X}$, which does not guarantee that the components will optimally predict $Y$ (Ferreira et al., 2017). A simultaneous decomposition of $X$ and $Y$ is performed by PLSR to create components that explain as much variation between $\mathrm{X}$ and $\mathrm{Y}$ as possible (Abdi and Williams, 2010; Carrascal et al., 2018; Ferreira et al., 2017).

Variable selection in PLSR is important because redundant variables can lead to low statistical significance (Martínez et al., 2017; Mehmood et al., 2012; Shi et al., 2013). A filter method was used to select the relevant variables with a threshold of 1 placed on the VIP score (Mehmood et al., 2012). A PLSR model was created for TP, SRP, TSS and SRP/TP. Regression coefficients along with VIP scores were used to determine the influence of the predictors on the response variables as per Zhou et al. (2017). The number of components were selected using root mean squared error of prediction (RMSEP) with 
the leave one out cross validation (LOO) method. Coefficient of determination $\left(R^{2}\right)$ and goodness of prediction $\left(Q^{2}\right)$ were used to assess the predictive ability of the model. A model with a $Q^{2}$ of greater than 0.5 is considered to have good predictive power (Shi et al., 2013).

In addition to a PLSR, we conducted a PCA on all predictors to visualize correlations between predictors. Principal component analysis is a descriptive technique that uses orthogonal scores to convert potentially correlated variables into uncorrelated principal components (Abdi and Williams, 2010). The PCA loading plots can be used to identify variables that are highly collinear, which can be used to better interpret PLSR models. All statistical analyses were done in RStudio ( $R$ version 3.5.1) (R Core Team, 2018), the PLSR which was conducted through the use of the "pls" package in R (Mevik et al., 2019).

\subsection{Results}

\subsubsection{TP, SRP, SRP/TP and TSS Concentrations}

Concentrations for TP, SRP, and TSS were significantly higher during stormflow for multiple sites (Figure 3), which seems to suggest that phosphorus and TSS increase in Innisfil Creek during storm events via flushing of sediments and decaying organic matter from surrounding fields and ditches. The drainage ditch (dd1) site had the highest concentrations of TP and SRP, exceeding $0.3 \mathrm{mgL}^{-1}$ and $0.25 \mathrm{mgL}^{-1}$ respectively (Figure 3). Concentrations for SRP along Innisfil Creek (i1 - i6) during stormflow were generally higher than other sites and decreased as one moved downstream. Median concentrations for TP, SRP, SRP/TP and TSS were used instead of the mean concentrations, because using median concentrations limits the influence of outliers and values close to the detection limit (Robertson et al., 2006). 


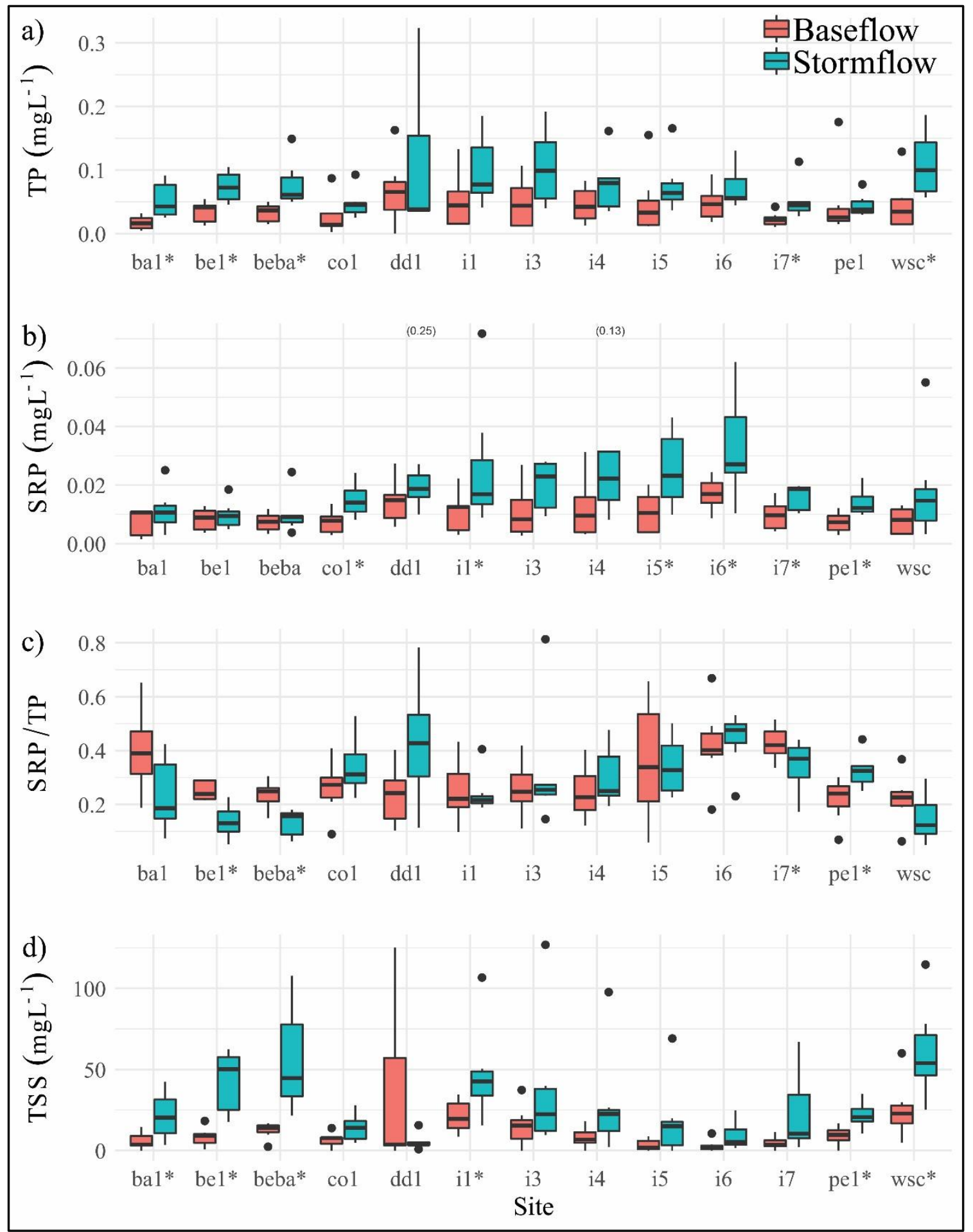

Figure 3. Boxplots summarizing: a) TP $\left(\mathrm{mgL}^{-1}\right)$, b) SRP $\left(\mathrm{mgL}^{-1}\right)$, c) SRP/TP, and d) TSS $\left(\mathrm{mgL}^{-1}\right)$ concentrations under baseflow and stormflow conditions at each synoptic survey site over the study period. Line represents the median, upper and lower hinges correspond to the first and third quartiles and whiskers extend from hinges to $1.5 *$ interquartile range. Values in brackets at top of panel represent outliers that are not displayed. Asterisks beside site labels on $\mathrm{x}$-axes indicate significant 
difference between baseflow and stormflow concentrations $(p<0.05)$ for each site via MannWhitneyWilcoxon test.

3.4.2. PLSR Models for TP, SRP and SRP/TP

\subsubsection{TP}

The baseflow TP model required five components with a cumulative $Q^{2}$ of 0.3126 (Table 2). Elevation was negatively related to TP and had the strongest influence on the model (high VIP, and negative regression coefficient, Figure 4a). The stormflow model for TP performed much better as it required one component and still had a higher $\mathrm{Q}^{2}$ value than baseflow TP (Table 2). Area, Strahler order, and 'other vegetables' had the highest VIP values in the stormflow model. All three of these variables had positive regression coefficients.

Table 2. Performance summary of all PLSR models.

\begin{tabular}{crcc}
\hline Variable & Component & $\mathrm{R}_{\text {2cum }}$ & \multicolumn{1}{c}{$\mathrm{Q}_{\text {2cum }}$} \\
\hline & 1 & 0.3877 & -0.6841 \\
Baseflow TP & 2 & 0.6002 & -0.9449 \\
& 3 & 0.8797 & -0.887 \\
& 4 & 0.9264 & 0.1104 \\
& 5 & 0.9408 & 0.3126 \\
\hline Stormflow TP & 1 & 0.5865 & 0.3837 \\
\hline Baseflow SRP & 1 & 0.5496 & 0.1952 \\
& 2 & 0.7142 & 0.3396 \\
\hline Stormflow SRP & 1 & 0.8202 & 0.6916 \\
\hline Baseflow SRP/TP & 1 & 0.483 & 0.1555 \\
\hline Stormflow SRP/TP & 1 & $\underline{0.751}$ & $\underline{0.6502}$ \\
\hline Baseflow TSS & 1 & 0.5188 & 0.2505 \\
\hline Stormflow TSS & 1 & 0.7804 & 0.6513 \\
\hline
\end{tabular}

$* Q^{2}$ cum: Cumulative goodness of prediction. $\mathrm{R}_{\text {cum: }}^{2}$ Cumulative coefficient of determination 


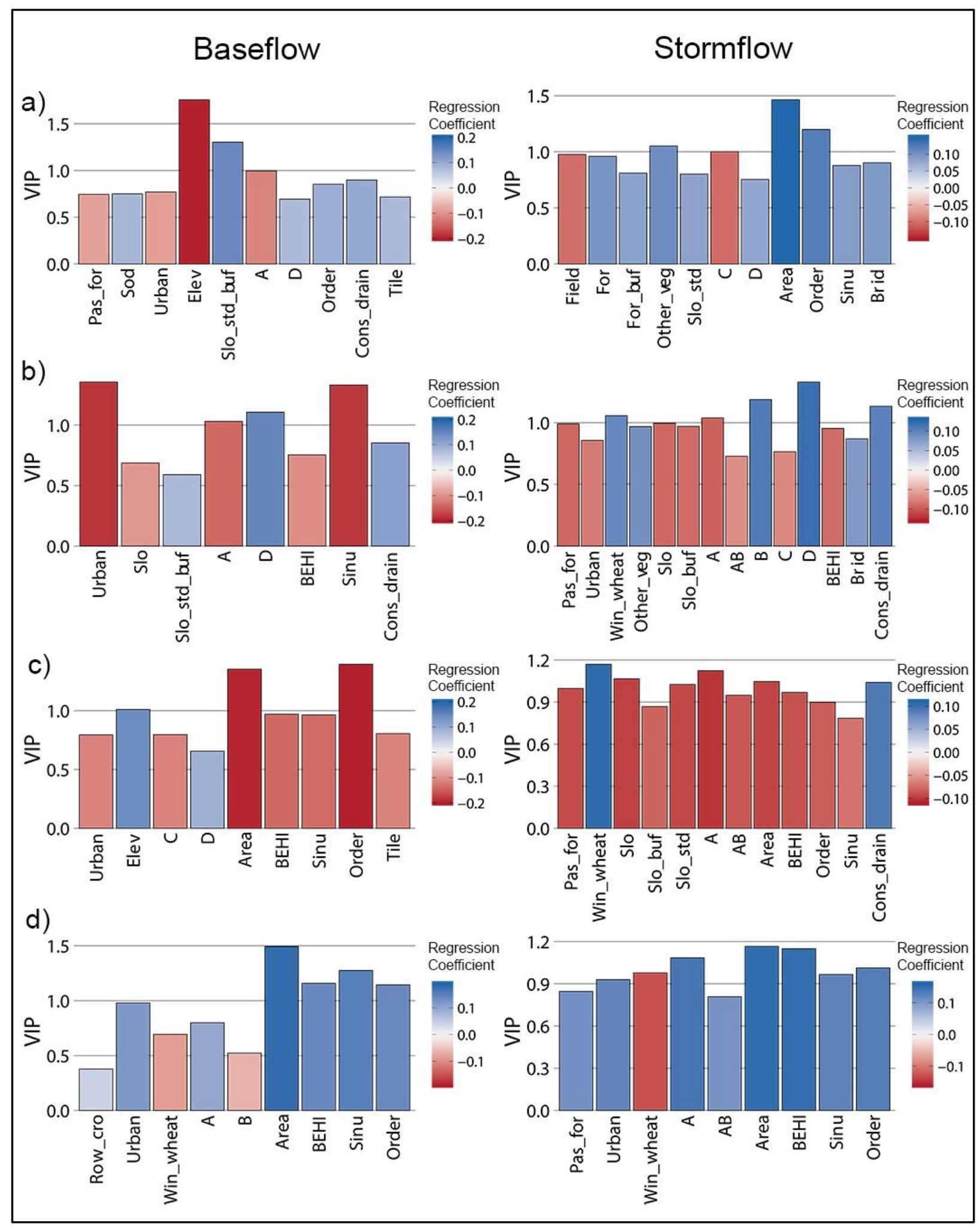

Figure 4. The PLSR results (VIP values [bars] and regression coefficients [bar colour]) for component 1 of the baseflow and stormflow: (a) TP, (b) SRP, (c) SRP/TP, and (d) TSS models. 


\subsubsection{SRP}

The baseflow model for SRP performed more poorly than the stormflow model (Table 2). It required two components to explain the variation in SRP during baseflow, while the stormflow model had a better $Q^{2}$ with only one component. The cumulative $Q^{2}$ for the baseflow model was 0.3396 and the two components explained $71.42 \%$ of the variation in baseflow SRP (Table 2). Percent urban land cover and mean sinuosity had the highest VIP scores, but hydrologic soil group A $(<10 \%$ clay and $>90 \%$ sand or gravel) and D ( $>40 \%$ clay and $<50 \%$ sand) also had VIP scores $>1$ (Figure $4 b$ ). Sinuosity, percent urban, and hydrologic soil group A had negative coefficients, indicating a negative correlation with baseflow SRP. A positive regression coefficient for constructed drain density and a negative coefficient for sinuosity indicates that channelized watercourses are associated with elevated SRP concentrations (Figure 4b). The stormflow model of SRP required one component with a $Q^{2}$ of 0.6916 and explained 82.02\% of variation in Y (Table 2). Hydrologic soil group D had the largest VIP score in the model, while Hydrologic soil group B, constructed drain density, percent winter wheat and hydrologic soil group A all had VIP values greater than one (Figure 4b). With the exception of hydrologic soil group A, all variables with a VIP value greater than one were positively correlated with stormflow SRP (Figure 4b). The high VIP value for constructed drain density indicates that tile drainage plays a major role in explaining SRP variance during stormflow.

\subsubsection{SRP/TP}

The baseflow model for SRP/TP also performed somewhat poorly when compared to the stormflow model (Table 2). The model required one component with a $Q^{2}$ of 0.1555 and explained $48.4 \%$ of the variation in baseflow SRP/TP. Area and stream order had the highest VIP values out of all variables examined and both variables were negatively correlated with SRP/TP ratios during baseflow (Figure 4c). Elevation also had a VIP value greater than one and was positively correlated with SRP/TP ratios. Lower order streams appear to have TP concentrations that have a relatively high proportion of SRP. The model results indicate that SRP/TP ratio is largely influenced by TP variability during baseflow because the baseflow TP model shows that areas with low elevations (downstream area) have higher TP concentrations. This is consistent with the baseflow SRP/TP model, which indicates that downstream areas have SRP/TP ratios dominated by TP. The stormflow model of SRP/TP performed well, as it required one component with a $Q^{2}$ of 0.6502 and explained $75.1 \%$ of the variation in stormflow SRP/TP 
(Table 2). Winter wheat, hydrologic soil group A, constructed drain density, area, slope, and standard deviation of slope all had a VIP value greater than one (Figure 4c). All variables with a VIP value greater than one were negatively correlated with stormflow SRP/TP, with the exception of winter wheat and constructed drain density. The model results indicate that winter wheat had a major influence on the proportion of SRP in TP. Winter wheat can serve as a source of SRP via fertilizer application and decaying vegetation, but is also used as a cover crop, which prevents soil erosion, potentially reducing PP inputs. Hydrologic soil groups play a much larger role in the stormflow SRP/TP model than in the baseflow model, likely due to the ability of soil texture and runoff potential to influence SRP concentrations during storm events. Like the stormflow model for SRP, constructed drain density correlates with an increase in SRP relative to TP. The stormflow model for SRP/TP is similar to the stormflow model of TP, because constructed drain density, winter wheat, and hydrologic soil groups had the largest influence on both models. This indicates that changes in the SRP/TP ratio are largely controlled by changes in the SRP concentrations during stormflow.

\subsubsection{TSS}

The baseflow model of TSS had a $Q^{2}$ of 0.2505 and explained $51.88 \%$ of variation in baseflow TSS (Table 2). Area, BEHI, sinuosity, and Strahler order all had VIP values greater than one and all of them were positively correlated with baseflow TSS (Figure 4d). These results indicate that stream characteristics primarily determine TSS concentrations in Innisfil Creek during baseflow. The stormflow model of TSS performed better than the baseflow model as it had a $Q^{2}$ of 0.6513 and explained $78.04 \%$ of variance in stormflow TSS (Table 2). Area, BEHI, hydrologic soil group A, and Strahler order all had a VP value greater than one, and these variables were positively correlated with stormflow TSS. The stormflow TSS results had a better $Q^{2}$ value, but had very similar VIP values in comparison with the baseflow TSS model. However, the stormflow TSS model saw an increase in VIP values for winter wheat and hydrologic soil group A.

\subsubsection{Collinearity in Predictors}

The PCA required 3 components to explain $79 \%$ of variation. The loading plot (Figure 5 ) indicates that all slope variables, BEHI, percent pasture and forages, Strahler order, mean sinuosity, percent urban, subcatchment area, and hydrologic soil Groups $A$ and $A B$ were positively correlated with each other but negatively correlated with PC1. Field, row crops, and tile drainage area were positively correlated with 
each other and positively correlated with PC1. Hydrologic soil group C was positively correlated with PC2, while other vegetables, bridges, and hydrologic soil groups B and D were positively correlated with each other but negatively correlated with PC2.

Due to the high multi-collinearity between the predictors in the PLSR models, it can be difficult to determine which variables are most related to the response. The principal component analysis can help address this issue. After identifying a few key variables from the PLSR model, we can use the principal components to identify other similarly correlated variables, which may explain variation in the response variable. Variables describing anthropogenic influence are best described by PC1. Many of the variables that represent anthropogenic activity, such as constructed drain density and row crops, are positively correlated with PC1 (Figure 5). Whereas variables that represent an undisturbed landscape, such as percent forest cover, are negatively correlated with PC1. PC2 can be interpreted as an index of catchments with increasing cover of hydrologic soil group $C$ and decreasing numbers of bridges, other vegetables, and hydrologic soil groups B \& D. 


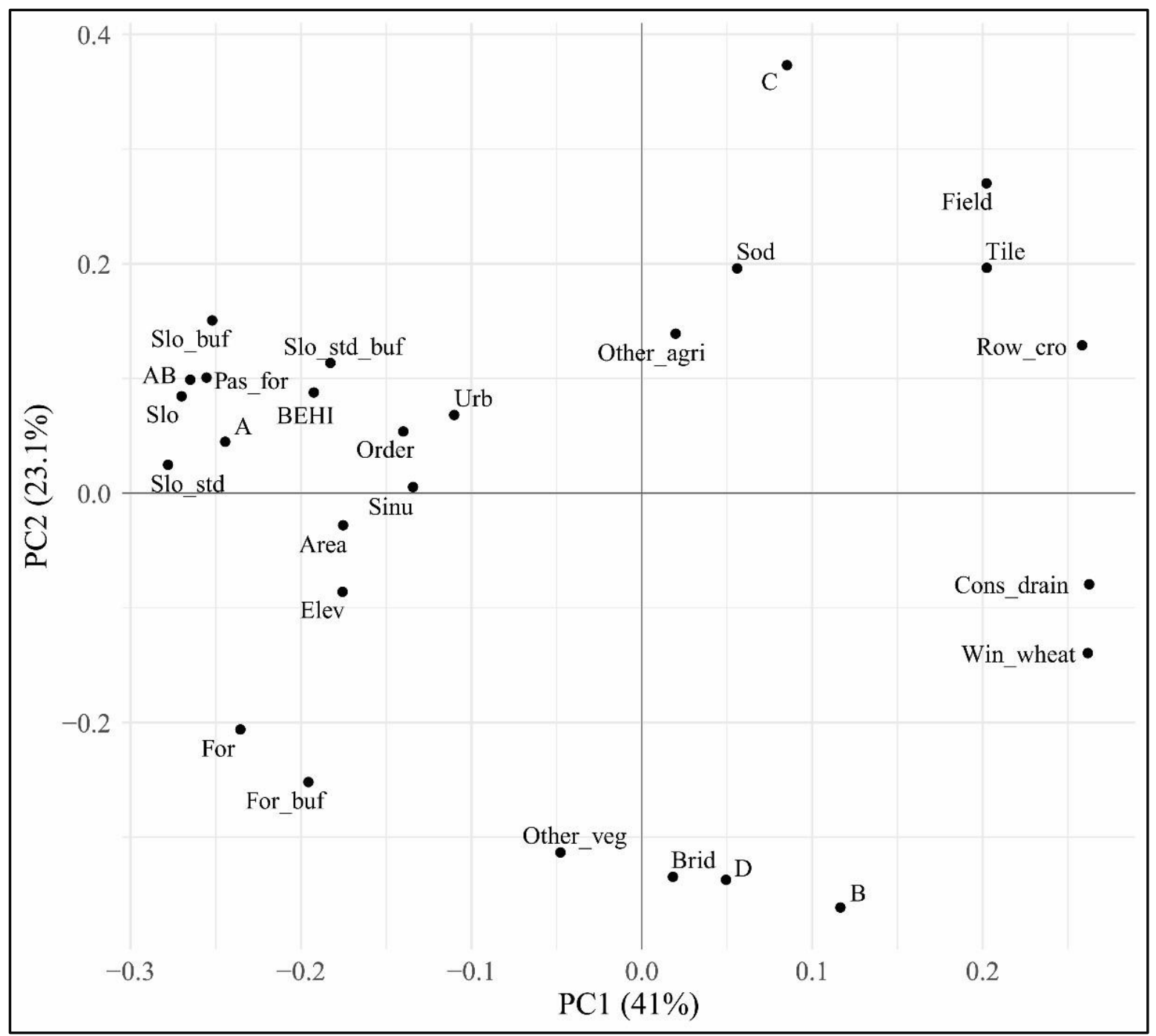

Figure 5. PCA loading plot for all 30 predictors. Principal component 1 (PC1) and principal component 2 (PC2) displayed.

\subsection{Discussion}

\subsubsection{Influence of flow state on nutrient concentrations}

All stormflow models had higher $\mathrm{Q}^{2}$ and $\mathrm{R}^{2}$ values compared to baseflow models. More importantly, the influence of land cover, topography, slope and soil were more pronounced during stormflow, likely due to increased hydrological connectivity during storm events. Previous studies (Arheimer and Lide, 2000; Haygarth et al., 2005) attributed elevated nutrient concentrations to diffuse agricultural sources, while the lower concentrations during baseflow were primarily attributed to point sources. The poor 
predictive performance of the baseflow PLSR models relative to the stormflow models suggest that point sources are likely not a major influence on baseflow concentrations in Innisfil Creek.

\subsubsection{Influence of land use / land cover on nutrient and TSS concentrations}

Percent urban had a negative regression coefficient and had the highest VIP value in the baseflow SRP model. A variety of studies have shown urban areas to be a potential source of nutrients (e.g., Golden et al., 2016; Paul et al., 2001), however, we found no other study that showed a strong negative relationship between SRP and urban areas. Another possible explanation for the baseflow SRP model is that agricultural land is more dominant than urban land cover, and agriculture is a larger source of SRP than urban areas. Figure 5 shows that urban land cover is correlated with a variety of variables, which likely also exert an influence on baseflow SRP. In contrast, agricultural classes (winter wheat and other vegetables) had greater VIP scores in the SRP stormflow model, which indicates that land cover may have a greater influence on SRP during stormflow than baseflow.

Multiple studies have found percent agricultural land cover to be a primary cause of elevated nutrient concentrations during both baseflow and stormflow conditions (Haygarth et al., 2005; Zhou et al., 2017). Only the stormflow models for TP, SRP and SRP/TP had any agricultural classes with a significant VIP value $(>1)$. None of the models we tested had an agricultural class as the most dominant variable related to variability in the response variable. Winter wheat and row crops were the only agricultural classes with a standard deviation greater than $5 \%$ (Table 3). We reason that lack of variability in agricultural classes within Innisfil Creek sub-catchments may explain why agricultural classes were not important variables in any of our models. In addition, we caution that the baseflow SRP model, should not be over interpreted given the poor predictive performance of this model. In summary, winter wheat and other vegetables were the only land cover variables that were significant in any PLSR models with good predictive ability.

Winter wheat is a cover crop that makes up almost $10 \%$ of Innisfil Creek's catchment area and it had high importance in the stormflow SRP, SRP/TP and TSS models. Studies by (Cober et al., 2019; Lozier et al., 2017) show that cover crops can be a source of SRP. The results of this study support this claim as winter wheat had a high VIP value and had a positive regression coefficient in the SRP and SRP/TP models. In addition, the stormflow TSS model indicates that winter wheat may assist in reducing TSS 
concentrations. Singh et al. (2018) also found cover crops to reduce TSS export and surface runoff during storm events.

Table 3. Summary statistics of all predictor variables along with values at the outlet of Innisfil Creek (wsc).

\begin{tabular}{|c|c|c|c|c|c|c|}
\hline Group & Variable & $\begin{array}{l}\text { Values for } \\
\text { the entire } \\
\text { catchment } \\
\text { (wsc) }\end{array}$ & Maximum & Minimum & Mean & $\begin{array}{l}\text { Standard } \\
\text { deviation }\end{array}$ \\
\hline \multirow{10}{*}{$\begin{array}{l}\text { Land Use / } \\
\text { Land Cover }\end{array}$} & Percent Field & 56.60 & 79.60 & 47.18 & 58.22 & 9.998 \\
\hline & Percent Forest & 17.22 & 23.74 & 5.46 & 16.18 & 6.300 \\
\hline & Percent Riparian Forest & 39.31 & 47.87 & 16.66 & 37.63 & 9.759 \\
\hline & Percent Other Agriculture & 2.62 & 6.10 & 0.44 & 2.33 & 1.556 \\
\hline & Percent Other Vegetables & 1.49 & 6.17 & 0.04 & 1.99 & 2.102 \\
\hline & Percent Pasture and Forage & 25.86 & 34.09 & 19.17 & 24.40 & 4.965 \\
\hline & Percent Row Crops & 30.27 & 47.57 & 20.67 & 30.42 & 8.230 \\
\hline & Percent Sod & 1.10 & 5.14 & 0.09 & 0.90 & 1.332 \\
\hline & Percent Urban and Developed & 6.61 & 12.01 & 4.22 & 6.47 & 2.060 \\
\hline & Percent Winter Wheat & 9.63 & 21.00 & 3.50 & 12.52 & 5.227 \\
\hline \multirow{5}{*}{ Topography } & Mean Elevation (metres) & 257.70 & 272.22 & 240.03 & 259.27 & 8.262 \\
\hline & Mean Slope (degrees) & 3.06 & 3.87 & 2.502 .86 & 2.96 & 0.400 \\
\hline & Mean Slope (Buffer) & 3.35 & 3.97 & \multirow{2}{*}{2.13} & 3.18 & 0.388 \\
\hline & $\begin{array}{l}\text { Mean Standard Deviation of } \\
\text { slope }\end{array}$ & 3.03 & 3.30 & & 2.85 & 0.355 \\
\hline & $\begin{array}{l}\text { Mean Standard Deviation of } \\
\text { slope (Buffer) }\end{array}$ & 3.28 & 3.45 & 2.74 & 3.17 & 0.231 \\
\hline \multirow{5}{*}{$\begin{array}{l}\text { Hydrologic Soil } \\
\text { Groups }\end{array}$} & Percent Hydrologic Soil Group A & 7.56 & 19.55 & 0.10 & 6.16 & 5.029 \\
\hline & $\begin{array}{l}\text { Percent Hydrologic Soil Group } \\
\text { AB }\end{array}$ & 14.76 & 36.32 & 0.10 & 10.03 & 11.867 \\
\hline & Percent Hydrologic Soil Group B & 35.67 & 71.59 & 17.48 & 43.42 & 21.157 \\
\hline & Percent Hydrologic Soil Group C & 32.57 & 69.18 & 7.72 & 30.57 & 19.780 \\
\hline & Percent Hydrologic Soil Group D & 8.21 & 18.27 & 0.10 & 8.77 & 5.812 \\
\hline \multirow{4}{*}{$\begin{array}{c}\text { Stream } \\
\text { Characteristics }\end{array}$} & Catchment Area $\left(\mathrm{km}^{2}\right)$ & 477.34 & 477.34 & 21.24 & 131.96 & 125.482 \\
\hline & Bank Erosion Hazard Index & 28.77 & 33.42 & 7.00 & 22.68 & 8.958 \\
\hline & Mean Sinuosity & 1.31 & 1.79 & 1.16 & 1.27 & 0.163 \\
\hline & Strahler Order & 7.00 & 7.00 & 3.00 & 5.00 & 1.080 \\
\hline \multirow{3}{*}{$\begin{array}{l}\text { Anthropogenic } \\
\text { Modifications }\end{array}$} & Bridge per km of Stream & 0.56 & 0.68 & 0.45 & 0.58 & 0.070 \\
\hline & $\begin{array}{l}\text { Constructed Drains Density } \\
\text { (Licensed) }\end{array}$ & 20.11 & 40.35 & 6.19 & 24.23 & 11.612 \\
\hline & $\begin{array}{l}\text { Percent Tile Drainage Area } \\
\text { (Licensed) }\end{array}$ & 16.39 & 30.72 & 8.69 & 16.72 & 6.916 \\
\hline
\end{tabular}




\subsubsection{Influence of topography on nutrient and TSS concentrations}

Some slope variables were 'important' and negatively correlated with stormflow SRP and SRP/TP concentrations (Figure 4b, c). These results contrast the findings of (Chang et al., 2008; Ekholm et al., 2000), who found slope to be positively correlated with nutrient concentrations. Our results did corroborate with Zhou et al. (2017), who also found slope to be negatively correlated with nutrient concentrations. The negative relationship of slope with stormflow SRP can be explained by the high correlation between slope and hydrologic soil group AB (Figure 5). The lack of topographic variables in the PLSR models can be attributed to the low variation between catchments. The standard deviation of both slope variables was less than one (Table 3). Innisfil Creek is a relatively flat catchment, thus the role of mean catchment slope on phosphorus concentrations might be insignificant compared to other variables. Topography was not a major control on nutrient and TSS concentrations according to the PLSR models.

\subsubsection{Influence of hydrologic soil groups on nutrient and TSS concentrations}

Golden et al. (2016) found hydrologic soil groups explain a large amount of variation in TP, while Arheimer and Lide (2000) found concentrations of all phosphorus species including TP to be positively correlated with clay dominated soils. The PLSR results indicate that hydrologic soil groups explain significant variation in SRP, stormflow SRP/TP and stormflow TSS. Surprisingly, hydrologic soil group A was positively correlated with stormflow TSS. This is likely due to the high collinearity between soil group A and other metrics associated with elevated TSS concentrations such as slope and BEHI (Figure $5)$.

Hydrologic soil group B was also positively correlated with stormflow SRP, possibly because soil group B is highly correlated with soil group D, which is associated with elevated SRP concentrations. The results of the stormflow SRP and SRP/TP PLSR models corroborate with the results of Arheimer and Lide (2000) who found finer soil texture to be associated with elevated SRP concentrations. However, hydrologic soil groups did not show the same relationships in the stormflow TP model, which does not support the results of either Arheimer and Lide (2000) or Golden et al. (2016) who found finer soil texture to be associated with elevated TP concentrations. This might be explained by the overwhelming influence of catchment area on TP variability. 


\subsubsection{Influence of stream characteristics on nutrient and TSS concentrations}

Catchment area was an important variable for explaining TP variation during stormflow and explaining variation in SRP/TP and TSS during all flows. There is an inherent (nested) spatial relationship between sampling sites, which means that the concentrations are not spatially independent. Thus, the high VIP value for area can be attributed to upstream concentrations influencing downstream concentrations. Both $\mathrm{BEHI}$ and sinuosity can serve as predictors for bank erosion and the presence of these variables in the TSS model along with area indicates that TSS is largely influenced by bank erosion. According to Gianfagna et al. (2015) catchment area can serve as a proxy for flow, which means a high VIP value for area with a positive regression coefficient can indicate that flow primarily controls the variability in the response variables. An increase in flow can lead to increased shear stress on stream banks leading to more bank erosion (Janes et al., 2018). Based on the TSS PLSR models, bank erosion is likely the primary control for TSS variation due to the high VIP values of area and other variables associated with bank erosion such BEHI and sinuosity.

\subsubsection{Influence of anthropogenic modifications on nutrient and TSS concentrations}

Agricultural dredging and channelization has a long history in Innisfil Creek and these practices have led to the destabilization of the stream banks and beds (I. Ockenden, personal communication, May 15, 2019). In addition, the majority of agricultural land is artificially drained through subsurface tile drains and/or open drainage channels running between fields. Constructed drain density was an important predictor in the stormflow models for SRP and SRP/TP, which indicates that constructed drains contribute to a large amount of SRP export in Innsifil Creek. Multiple studies demonstrate that tile drains are a significant source of nutrients and sediments in agricultural landscapes (Gentry et al., 2007; Macrae et al., 2007; McDowell and Wilcock, 2004; Van Esbroeck et al., 2016). None of the anthropogenic modification variables had a significant VIP value in any of the baseflow models. The lack of importance of these variables during baseflow indicates that point sources may not have large control on TP, SRP, SRP/TP and TSS values. However, it is important to note that tile drainage area and constructed drains would likely never be active during baseflow, which explains why they did not have VIP values greater than one in any baseflow models. Field observations indicated that bridges were associated with exposed banks in Innisfil Creek. In this study, the variable, bridges, included all river crossings, many smaller crossings likely did not have exposed banks. In addition, the standard deviation of bridges might be too small to adequately capture the variation in bridges across Innisfil Creek (Table 
3). Although constructed drain density was highly important in explaining the variation in stormflow SRP and SRP/TP, none of the anthropogenic modification variables were important in any baseflow PLSR models.

\subsubsection{Management implications and future directions}

In this study, we attempted to understand the influence of flow state and landscape characteristics on nutrient and TSS concentrations over the span of one year with 13 sample sites in a large catchment.

Our study indicates that landscape influences on phosphorus and TSS concentrations are much more evident during stormflow conditions. Hydrologic soil groups and upstream catchment area had the largest influence on nutrient concentrations during stormflow conditions, while TSS concentrations are likely primarily controlled by bank erosion during storm flows in Innisfil Creek. We found BEHI to be an effective predictor of TSS concentrations in Innisfil Creek, which has traditionally been used to predict stream bank erosion. To our knowledge, no other study has attempted to use BEHI to predict TSS variability. Our results indicate that BEHI can serve as a good predictor of TSS variability and may have the potential to identify TSS source areas along a stream network.

Constructed drain density, had a high VIP value in the stormflow SRP model, which indicates that constructed drains may play a large role in controlling SRP concentrations in Innisfil Creek and may also play a large role in controlling SRP concentrations in Innisfil Creek. Percent winter wheat also had a high VIP values in the stormflow SRP model and was highly correlated with constructed drain density (Figure 5). Thus, it is unclear which variable actually controls the variation in stormflow SRP. The results of this study highlights the need for accurate, high spatial resolution tile drainage mapping. Tile drains can be a significant pathway of phosphorus, but are rarely mapped. This study used constructed drain density, a generic variable that represents any channelized drains and includes both surface and subsurface drains. In addition, constructed drain density only included drains installed by licensed contractors, and did not include tile drains installed by individual farmers. Subsurface flows export a large proportion of TP and SRP in other Ontario catchments (Macrae et al., 2007; Van Esbroeck et al., 2016), but constructed drains were only an important pathway for SRP in this study. This result may be attributed to the underrepresentation of tile drains by the constructed drains variable.

Future research could expand on this investigation further by conducting more surveys over a longer period of time, with more survey sites to better understand the influence of landscape characteristics on 
phosphorus and TSS. Additional survey sites, the addition of PP, and the adequate mapping of the tile drainage system in Innisfil Creek would lead to a better understanding of the role of tile drains on nutrient and TSS concentrations at a catchment scale. The results of this study highlight the potential effectiveness of BEHI to predict TSS concentrations. Future studies can use BEHI to predict the variability of PP and TSS. By using BEHI along with land cover variables it may be possible to determine the proportion of TSS mobilized from stream banks, relative to TSS from agricultural runoff, over a variety of flow conditions.

\subsubsection{Hypothesis Generation}

The ability for PLSR to incorporate a large number of predictor variables is both its greatest strength and greatest weakness. Although PLSR can address multi-collinearity it cannot disentangle highly correlated variables. This makes PLSR ineffective at identifying primary drivers but an ideal choice for hypothesis generation, as it can narrow down the number of possible catchment and hydrological controls on nutrient concentrations. Tile drains can potentially lead to elevated nutrient concentrations because they do not interact with riparian vegetation and feed directly into the stream. Yet, it is unclear whether tile drains in Innisfil Creek actually contribute to nutrient concentrations or if they are negatively correlated with sandy soils (group A) and positively correlated with percent winter wheat (Figure 5). We hypothesize that tile drains will generally be correlated with clay soils and contribute to increased nutrient concentrations in catchments with highly vegetated riparian areas. This hypothesis can be tested at the field scale, by measuring nutrient exports for plots with and without tile drains.

Hydrologic soil groups had high VIP values in the stormflow PLSR model and likely contribute to the elevated nutrient concentrations. However, it is unclear whether this is due to the increased ability of phosphorus to bind with fine textured soils or the increased runoff potential associated with fine textured soils. We hypothesize that the synergistic effect of increased sorption capacity and the increase in runoff potential contribute to elevated nutrient concentrations in Innisfil Creek. This hypothesis can potentially be tested by comparing soil texture and runoff potential in a paired catchment study.

According to the TSS PLSR models, variables associated with bank erosion appear to be the only variables with a high VIP value during baseflow, and variables associated with both bank erosion and landscape characteristics have high VIP values in the stormflow TSS model. We hypothesize that overland flow from agricultural fields and erosion of stream banks combine to control TSS 
concentrations during stormflow, whereas TSS concentrations are primarily controlled by erosion of streambanks only during baseflow. This hypothesis can potentially be tested by studying the influence of catchment area and BEHI on TSS concentrations in a catchment with varying riparian vegetation cover.

\section{Summary}

Anthropogenic eutrophication presents a major threat to ecosystem and human health. Eutrophication is defined by excessive enrichment of a waterbody, which leads to algal blooms and oxygen depletion.

Phosphorus is generally considered the limiting nutrient in freshwater systems, and phosphorus is often exported from agricultural land in southern Ontario. Large amounts of phosphorus applied to agricultural land as fertilizer and manure can be exported into nearby water bodies during and after precipitation events. Thus, understanding controls on phosphorus transport in agriculturally intensive catchments is key to reducing phosphorus input in freshwater bodies. Current literature suggests that phosphorus is generally transported via overland flows, however when soils are well saturated, subsurface transport via tile drainage systems can become a significant transport pathway. In addition to phosphorus, sediments can also be deleterious to aquatic systems. Elevated sediment concentrations in lotic systems can cause a decline in the richness of benthic and fish species.

Using PLSR and other statistical techniques, we studied the influence of 30 catchment characteristics on TP, SRP, SRP/TP and TSS concentrations in Innisfil Creek during both baseflow and stormflow. Innisfil Creek is a large $\left(477 \mathrm{~km}^{2}\right)$ catchment that is part of the greater Nottawasaga Valley watershed. This catchment is dominated by agricultural activity and has the highest TP concentrations compared to all other catchments in the Nottawasaga Valley watershed.

The PLSR models consistently performed better during stormflow than baseflow. This is likely due to the increased terrestrial-to-aquatic hydrologic connectivity during stormflow. Winter wheat was the only agricultural land cover class with a VIP value greater than one in any stormflow model; indeed winter wheat had a high VIP value and a positive regression coefficient with stormflow SRP. Topographic variables were generally not important in any stormflow PLSR models, with the exception of the stormflow SRP/TP model. Hydrologic soil groups had the largest influence on the stormflow PLSR models, especially on the stormflow SRP model. Hydrologic soil group D had the highest VIP value along with a positive regression coefficient with stormflow SRP. Soils with fine texture, such as clays, have a 
high sorption capacity and a low infiltration rate, which can facilitate the overland runoff of phosphorus. Stream characteristic (BEHI, catchment area and mean sinuosity) variables were generally important in both baseflow and stormflow TSS models. The TSS models indicate that bank erosion is likely the primary source of TSS in Innisfil Creek. Constructed drains had a high VIP value in the stormflow SRP model, indicating that a significant proportion of SRP is exported via subsurface flows in Innisfil Creek.

This study showed the importance of constructed drains as a possible transport pathway for SRP, which indicates a need for comprehensive tile drainage data and high-frequency monitoring of nutrient concentrations in water draining from tiles. Constructed drains was an important predictor even though this variable only represented licensed tile drainage systems, which do not represent all the tile drains present in Innisfil Creek. It is unclear how the addition of an entirely representative tile drainage dataset would affect the results of this study. Another important contribution we found was that BEHI was an important predictor of TSS concentrations. Traditionally, BEHI has only been used to predict stream bank erosion: this study indicates that BEHI may also be effective in predicting stream TSS concentrations. 


\section{References}

Abdi, H., 2010. Partial least squares regression and projection on latent structure regression (PLS Regression). Wiley Interdiscip. Rev. Comput. Stat. 2, 97-106. https://doi.org/10.1002/wics.51

Abdi, H., Williams, L.J., 2010. Principal component analysis. Wiley Interdiscip. Rev. Comput. Stat. 2, 433-459. https://doi.org/10.1002/wics.101

Alberto, A., St-Hilaire, A., Courtenay, S.C., van den Heuvel, M.R., 2016. Monitoring stream sediment loads in response to agriculture in Prince Edward Island, Canada. Environ. Monit. Assess. 188. https://doi.org/10.1007/s10661-016-5411-3

Algoazany, A.S., Kalita, P.K., Czapar, G.F., Mitchell, J.K., 2007. Phosphorus Transport through Subsurface Drainage and Surface Runoff from a Flat Watershed in East Central Illinois, USA. J. Environ. Qual. 36, 681-693.

Allmanová, Z., Jakubis, M., 2016. Is the BEHI Index (Part of the BANCS Model) Good for Prediction of Streambank Erosion? Acta Univ. Agric. Silvic. Mendelianae Brun. 64, 1107-1114. https://doi.org/10.11118/actaun201664041107

Arheimer, B., Lide, R., 2000. Nitrogen and phosphorus concentrations from agricultural catchments - influence of spatial and temporal variables. J. Hydrol. 227, 140-159.

Banner, E.B.K., Stahl, A.J., Dodds, W.K., 2009. Stream discharge and riparian land use influence Instream concentrations and loads of phosphorus from central plains watersheds. Environ. Manage. 44, 552-565. https://doi.org/10.1007/s00267-009-9332-6

Bernot, M.J., Tank, J.L., Royer, T. V., David, M.B., 2006. Nutrient uptake in streams draining agricultural catchments of the midwestern United States. Freshw. Biol. 51, 499-509. https://doi.org/10.1111/j.1365-2427.2006.01508.x

Bhattarai, R., Kalita, P.K., Patel, M.K., 2009. Nutrient transport through a Vegetative Filter Strip with subsurface drainage. J. Environ. Manage. 90, 1868-1876. https://doi.org/10.1016/j.jenvman.2008.12.010

Brunsdon, C., Fotheringham, A.S., Charlton, M.E., 1996. Geographically Weighted Regression: A Method for Exploring Spatial Nonstationarity. Geogr. Anal. 28, 281-298. https://doi.org/10.1111/j.1538-4632.1996.tb00936.x

Burdon, F.J., McIntosh, A.R., Harding, J.S., 2013. Habitat loss drives threshold response of benthic invertebrate communities to deposited sediment in agricultural streams. Ecol. Appl. 23, 1036-1047. https://doi.org/10.1890/12-1190.1

Burrell, T.K., Brien, J.M.O., Graham, S.E., Simon, K.S., Harding, J.S., Mcintosh, A.R., Burrell, T.K., Brien, J.M.O., Graham, S.E., Simon, K.S., Harding, J.S., Mcintosh, A.R., 2013. Riparian shading mitigates stream eutrophication in agricultural catchments. Freshw. Sci. 33, 73-84. https://doi.org/10.1086/674180. 
Carrascal, L., Galvan, I., Gordo, O., 2018. Nordic Society Oikos Partial Least Squares Regression as an Alternative to Current Regression Methods Used in Ecology. Oikos 118, 681-690.

Cerdà, A., Flanagan, D.C., le Bissonnais, Y., Boardman, J., 2009. Soil erosion and agriculture. Soil Tillage Res. 106, 107-108. https://doi.org/10.1016/j.still.2009.10.006

Chow-Fraser, P., 2006. A study of water-quality conditions of the Innisfil Creek and Nottawasaga River before and after a summer storm event.

Cober, J.R., Macrae, M.L., Van Eerd, L.L., 2019. Winter Phosphorus Release from Cover Crops and Linkages with Runoff Chemistry. J. Environ. Qual. 0, 0. https://doi.org/10.2134/jeq2018.08.0307

Conley, D.J., Paerl, H.W., Howarth, R.W., Boesch, D.F., Seitzinger, S.P., Havens, K.E., Lancelot, C., Likens, G.E., 2009. ECOLOGY: Controlling Eutrophication: Nitrogen and Phosphorus. Science (80-. ). 323, 1014-1015. https://doi.org/10.1126/science.1167755

Dilts, T., 2015. Stream Gradient \& Sinuosity Toolbox for ArcGISv10.

Ding, Y., Harwood, A.D., Foslund, H.M., Lydy, M.J., 2010. Distribution and toxicity of sedimentassociated pesticides in urban and agricultural waterways from Illinois, USA. Environ. Toxicol. Chem. 29, 149-157. https://doi.org/10.1002/etc.13

Doody, D., Moles, R., Tunney, H., Kurz, I., Bourke, D., Daly, K., O’Regan, B., 2006. Impact of flow path length and flow rate on phosphorus loss in simulated overland flow from a humic gleysol grassland soil. Sci. Total Environ. 372, 247-255.

https://doi.org/10.1016/j.scitotenv.2006.08.029

Dupas, R., Delmas, M., Dorioz, J.-M., Garnier, J., Moatar, F., Gascuel-Odoux, C., 2015a. Assessing the impact of agricultural pressures on $\mathrm{N}$ and $\mathrm{P}$ loads and eutrophication risk. Ecol. Indic. 48, 396-407. https://doi.org/10.1016/j.ecolind.2014.08.007

Dupas, R., Gascuel-Odoux, C., Gilliet, N., Grimaldi, C., Gruau, G., 2015b. Distinct export dynamics for dissolved and particulate phosphorus reveal independent transport mechanisms in an arable headwater catchment. Hydrol. Process. 29, 3162-3178.

https://doi.org/10.1002/hyp.10432

Ellison, M.E., Brett, M.T., 2006. Particulate phosphorus bioavailability as a function of stream flow and land cover. Water Res. 40, 1258-1268. https://doi.org/10.1016/j.watres.2006.01.016

Environment Canada, 2018. Canadian Climate Normals 1981-2010 Station Data [Data]. URL http://climate.weather.gc.ca/climate_normals/results_1981_2010_e.html?searchType=stnPr ox\&txtRadius $=25 \&$ selCity $=\&$ selPark=\&optProxType=custom \&txtCentralLatDeg=44\&txtCentral LatMin=12\&txtCentralLatSec=31\&txtCentralLongDeg=79\&txtCentralLongMin=39\&txtCentralL ong

Environment Canada, 2013. How much habitat is enough? 
Ferreira, A.R.L., Fernandes, L.F.S., Cortes, R.M. V, Pacheco, F.A.L., 2017. Science of the Total Environment Assessing anthropogenic impacts on riverine ecosystems using nested partial least squares regression. Sci. Total Environ. 583, 466-477.

https://doi.org/10.1016/j.scitotenv.2017.01.106

Fuchs, J.W., Fox, G.A., Storm, D.E., Penn, C.J., Brown, G.O., 2009. Subsurface Transport of Phosphorus in Riparian Floodplains: Influence of Preferential Flow Paths. J. Environ. Qual. 38, 473. https://doi.org/10.2134/jeq2008.0201

Fulweiler, R.W., Nixon, S.W., 2005. Export of nitrogen, phosphorus, and suspended solids from a southern New England watershed to Little Narragansett Bay. Biogeochemistry 76, 567-593. https://doi.org/10.1007/s10533-005-0444-7

Garófano-Gómez, V., Martínez-Capel, F., Peredo-Parada, M., Marín, E.J.O., Mas, R.M., Costa, R.M.S., Pinar-Arenas, J.L., 2011. Assessing hydromorphological and floristic patterns along a regulated Mediterranean river: The Serpis River (Spain). Limnetica 30, 307-328. https://doi.org/10.1002/rra

Gentry, L.E., David, M.B., Royer, T. V., Mitchell, C.A., Starks, K.M., 2007. Phosphorus Transport Pathways to Streams in Tile-Drained Agricultural Watersheds. J. Environ. Qual. 36, 408. https://doi.org/10.2134/jeq2006.0098

Gianfagna, C.C., Johnson, C.E., Chandler, D.G., Hofmann, C., 2015. Watershed area ratio accurately predicts daily streamflow in nested catchments in the Catskills, New York. J. Hydrol. Reg. Stud. 4, 583-594. https://doi.org/10.1016/j.ejrh.2015.09.002

Golden, H.E., Lane, C.R., Prues, A.G., D’Amico, E., 2016. Boosted Regression Tree Models to Explain Watershed Nutrient Concentrations and Biological Condition. J. Am. Water Resour. Assoc. 52, 1251-1274. https://doi.org/10.1111/1752-1688.12447

Haygarth, P.M., Wood, F.L., Heathwaite, A.L., Butler, P.J., 2005. Phosphorus dynamics observed through increasing scales in a nested headwater-to-river channel study. Sci. Total Environ. 344, 83-106. https://doi.org/10.1016/j.scitotenv.2005.02.007

Janes, V., Holman, I., Birkinshaw, S., O’Donnell, G., Kilsby, C., 2018. Improving bank erosion modelling at catchment scale by incorporating temporal and spatial variability. Earth Surf. Process. Landforms 43, 124-133. https://doi.org/10.1002/esp.4149

Janke, B.D., Finlay, J.C., Hobbie, S.E., Baker, L.A., Sterner, R.W., Nidzgorski, D., Wilson, B.N., 2014. Contrasting influences of stormflow and baseflow pathways on nitrogen and phosphorus export from an urban watershed. Biogeochemistry 121, 209-228. https://doi.org/10.1007/s10533-013-9926-1

King, K.W., Fausey, N.R., Williams, M.R., 2014. Effect of subsurface drainage on streamflow in an agricultural headwater watershed. J. Hydrol. 519, 438-445. https://doi.org/10.1016/j.jhydrol.2014.07.035 
King, K.W., Williams, M.R., Macrae, M.L., Fausey, N.R., Frankenberger, J., Smith, D.R., Kleinman, P.J.A., Brown, L.C., 2015. Phosphorus Transport in Agricultural Subsurface Drainage: A Review. J. Environ. Qual. 44, 467. https://doi.org/10.2134/jeq2014.04.0163

Kleinman, P.J.A., Sharpley, A.N., McDowell, R.W., Flaten, D.N., Buda, A.R., Tao, L., Bergstrom, L., Zhu, Q., 2011. Managing agricultural phosphorus for water quality protection: principles for progress. Plant Soil 349, 169-182. https://doi.org/10.1007/s11104-011-0832-9

Kronvang, B., Laubel, A., Grant, R., 1997. Suspended sediment and particulate phosphorus transport and delivery pathways in an arable catchment, Gelbaek Stream, Denmark. Hydrol. Process. 11, 627-642. https://doi.org/10.1002/(SICI)10991085(199705)11:6<627::AIDHYP481>3.0.CO;2-E

Kwan, H., Swanson, S., 2014. Prediction of Annual Streambank Erosion for Sequoia National Forest, California. J. Am. Water Resour. Assoc. 50, 1439-1447. https://doi.org/10.1111/jawr.12200

Labry, C., Youenou, A., Delmas, D., Michelon, P., 2013. Addressing the measurement of particulate organic and inorganic phosphorus in estuarine and coastal waters. Cont. Shelf Res. 60, 28-37. https://doi.org/10.1016/j.csr.2013.04.019

Lammers, R.W., Bledsoe, B.P., Langendoen, E.J., 2017. Uncertainty and sensitivity in a bank stability model: implications for estimating phosphorus loading. Earth Surf. Process. Landforms 42, 612-623. https://doi.org/10.1002/esp.4004

Larsen, S., Vaughan, I.P., Ormerod, S.J., 2009. Scale-dependent effects of fine sediments on temperate headwater invertebrates. Freshw. Biol. 54, 203-219. https://doi.org/10.1111/j.1365-2427.2008.02093.x

Lee, K.H., Isenhart, T.M., Schultz, R.C., 2003. Sediment and nutrient removal in an established multi-species riparian buffer. J. Soil Water Conserv. 58, 1-8.

Lenat, D.R., Penrose, D.L., Eagleson, K.W., 1981. Variable effects of sediment addition on stream benthos. Hydrobiologia 79, 187-194. https://doi.org/10.1007/BF00006126

Lovell, S.T., Sullivan, W.C., 2006. Environmental benefits of conservation buffers in the United States : Evidence, promise, and open questions. Agric. Ecosyst. Environ. 112, 249-260. https://doi.org/10.1016/j.agee.2005.08.002

Lozier, T.M., Macrae, M.L., Brunke, R., Van Eerd, L.L., 2017. Release of phosphorus from crop residue and cover crops over the non-growing season in a cool temperate region. Agric. Water Manag. 189, 39-51. https://doi.org/10.1016/j.agwat.2017.04.015

Lu, S., Kronvang, B., Audet, J., Trolle, D., Andersen, H.E., Thodsen, H., van Griensven, A., 2015. Modelling sediment and total phosphorus export from a lowland catchment: Comparing sediment routing methods. Hydrol. Process. 29, 280-294. https://doi.org/10.1002/hyp.10149 
Macrae, M.L., English, M.C., Schiff, S.L., Stone, M., 2007. Intra-annual variability in the contribution of tile drains to basin discharge and phosphorus export in a first-order agricultural catchment. Agric. Water Manag. 92, 171-182. https://doi.org/10.1016/j.agwat.2007.05.015

Martínez, J.L., Saulo, H., Escobar, H.B., Leao, J., 2017. A new model selection criterion for partial least squares regression. Chemom. Intell. Lab. Syst. 169, 64-78. https://doi.org/10.1016/j.chemolab.2017.08.006

Matthaei, C.D., Piggott, J.J., Townsend, C.R., 2010. Multiple stressors in agricultural streams: interactions among sediment addition, nutrient enrichment and water abstraction. J. Appl. Ecol. 47, 639-649. https://doi.org/10.1111/j.1365-2664.2010.01809.x

McDowell, R.W., Wilcock, R.J., 2004. Particulate Phosphorus Transport within Stream Flow of an Agricultural Catchment. J. Environ. Qual. 33, 2111. https://doi.org/10.2134/jeq2004.2111

McMillan, M., Liebens, J., Bagui, S., 2018. A statistical model for streambank erosion in the Northern Gulf of Mexico coastal plain. Catena 165, 145-156. https://doi.org/10.1016/j.catena.2018.01.027

Mehmood, T., Liland, K.H., Snipen, L., Sæbø, S., 2012. A review of variable selection methods in Partial Least Squares Regression. Chemom. Intell. Lab. Syst. 118, 62-69. https://doi.org/10.1016/j.chemolab.2012.07.010

Mellander, P.E., Jordan, P., Shore, M., Melland, A.R., Shortle, G., 2015. Flow paths and phosphorus transfer pathways in two agricultural streams with contrasting flow controls. Hydrol. Process. 29, 3504-3518. https://doi.org/10.1002/hyp.10415

Mevik, B.-H., Wehrens, R., Hovde, K., Hiemstra, P., 2019. Partial Least Squares and Principal Component Regression.

Ministry of Natural Resources and Forestry, 2017. Ontario flow assessment tool.

Monteagudo, L., Moreno, J.L., Picazo, F., 2012. River eutrophication: Irrigated vs. non-irrigated agriculture through different spatial scales. Water Res. 46, 2759-2771. https://doi.org/10.1016/j.watres.2012.02.035

Montgomery, D.R., 2007. Soil erosion and agricultural sustainability. Proc. Natl. Acad. Sci. 104, 13268-13272. https://doi.org/10.1073/pnas.0611508104

Munn, M., Frey, J., Tesoriero, A., 2010. The Influence of Nutrients and Physical Habitat in Regulating Algal Biomass in Agricultural Streams. Environ. Manage. 45, 603-615. https://doi.org/10.1007/s00267-010-9435-0

Naiman and, R.J., Décamps, H., 1997. The ecology of interfaces: Riparian zones. Annu. Rev. Ecol. Syst. 28, 621-658. https://doi.org/10.1146/annurev.ecolsys.28.1.621

Naiman, R.J.., Decamps, H., Pollock, M., 1993. The Role of Riparian Corridors in Maintaining 
Regional Biodiversity Author ( $\mathrm{s}$ ): Published by : Wiley on behalf of the Ecological Society of America Stable URL : http://www.jstor.org/stable/1941822 Wi. Ecol. Appl. 3, 209-212.

Nottawasaga Valley Conservation Authority (NVCA), 2013. Innisfil Creek 2013 Watershed.

O’Dell, J., 1993. Method 365.1 Determination of phosphorus by semi-automated colorimetry.

Ontario Ministry of Agriculture Food and Rural Affairs (OMAFRA), 2018. Tile Drainage Area [Data]. URL https://www.javacoeapp.Irc.gov.on.ca/geonetwork/srv/en/main.home

Ontario Ministry of Agriculture Food and Rural Affairs (OMAFRA), 2015a. Constructed Drain [Data].

Ontario Ministry of Agriculture Food and Rural Affairs (OMAFRA), 2015b. Soil Survey Complex [Data].

Pacini, N., Gächter, R., 1999. Speciation of riverine particulate phosphorus during rain events. Biogeochemistry 47, 87-109. https://doi.org/10.1023/A:1006153302488

Paul, M., Leigh, D., Lo, C., 2001. Urbanization in the Etowah River basin: effects on stream temperature and chemistry. Proc. 2001 Georg. Water ... 241-245.

Poirier, S.-C., Whalen, J.K., Michaud, A.R., 2011. Bioavailable Phosphorus in Fine-Sized Sediments Transported from Agricultural Fields. Soil Sci. Soc. Am. J. 76, 258. https://doi.org/10.2136/sssaj2010.0441

Pollen, N., Simon, A., 2005. Estimating the mechanical effects of riparian vegetation on stream bank stability using a fiber bundle model. Water Resour. Res. 41, 1-11. https://doi.org/10.1029/2004WR003801

Pope, I.C., Odhiambo, B.K., 2014. Soil erosion and sediment fluxes analysis: A watershed study of the Ni Reservoir, Spotsylvania County, VA, USA. Environ. Monit. Assess. 186, 1719-1733. https://doi.org/10.1007/s10661-013-3488-5

Pratt, B., Chang, H., 2012. Effects of land cover, topography, and built structure on seasonal water quality at multiple spatial scales. J. Hazard. Mater. 209-210, 48-58. https://doi.org/10.1016/j.jhazmat.2011.12.068

Preedy, N., McTiernan, K., Matthews, R., Heathwaite, L., Haygarth, P., 2001. Rapid incidental phosphorus transfers from grassland. J. Environ. Qual. 30, 2105-2112. https://doi.org/10.2134/jeq2001.2105

Prosdocimi, M., Calligaro, S., Sofia, G., Fontana, G.D., Tarolli, P., 2015. Bank erosion in agricultural drainage networks : new challenges from structure-from-motion photogrammetry for postevent analysis. Earth Surf. Process. Landforms 40, 1891-1906. https://doi.org/10.1002/esp.3767

R Core Team, 2018. R: A Language and Environment for Statistical Computing. 
Reynolds, C.S., Davies, P.S., 2001. Sources and bioavailability of phosphorus fractions in freshwaters: a British perspective. Biol. Rev. Camb. Philos. Soc. 76, 27-64. https://doi.org/10.1111/j.1469-185X.2000.tb00058.x

Rios, S.L., Bailey, R.C., 2006. Relationship between riparian vegetation and stream benthic communities at three spatial scales. Hydrobiologia 553, 153-160. https://doi.org/10.1007/s10750-005-0868-z

Robertson, D.M., Saad, D.A., Heisey, D.M., 2006. A regional classification scheme for estimating reference water quality in streams using land-use-adjusted spatial regression-tree analysis. Environ. Manage. 37, 209-229. https://doi.org/10.1007/s00267-005-0022-8

Rosgen, D.L., 2001. A Practical Method of Computing Streambank Erosion Rate. Proc. Seventh Fed. Interag. Sediment. Conf. March 25 to 29, 2001, Reno, Nevada 10. https://doi.org/10.1007/s13398-014-0173-7.2

Russell, M.A., Walling, D.E., Hodgkinson, R.A., 2001. Suspended sediment sources in two small lowland agricultural catchments in the UK. J. Hydrol. 252, 1-24. https://doi.org/10.1016/S0022-1694(01)00388-2

Saeys, Y., Inza, I., Larranaga, P., 2007. A review of feature selection techniques in bioinformatics. Bioinformatics 23, 2507-2517. https://doi.org/10.1093/bioinformatics/btm344

Sanchez, G.M., Nejadhashemi, A.P., Zhang, Z., Marquart-Pyatt, S., Habron, G., Shortridge, A., 2015. Linking watershed-scale stream health and socioeconomic indicators with spatial clustering and structural equation modeling. Environ. Model. Softw. 70, 113-127. https://doi.org/10.1016/j.envsoft.2015.04.012

Schilling, K.E., Gassman, P.W., Arenas-Amado, A., Jones, C.S., Arnold, J., 2019. Quantifying the contribution of tile drainage to basin-scale water yield using analytical and numerical models. Sci. Total Environ. 657, 297-309. https://doi.org/10.1016/j.scitotenv.2018.11.340

Schindler, D.W., Hecky, R.E., Findlay, D.L., Stainton, M.P., Parker, B.R., Paterson, M.J., Beaty, K.G., Lyng, M., Kasian, S.E.M., 2008. Eutrophication of lakes cannot be controlled by reducing nitrogen input: Results of a 37-year whole-ecosystem experiment. Proc. Natl. Acad. Sci. 105, 11254-11258. https://doi.org/10.1073/pnas.0805108105

Schultz, R.C., Isenhart, T.M., Simpkins, W.W., Colletti, J.P., 2004. Riparian forest buffers in agroecosystems - lessons learned from the Bear Creek Watershed, central lowa, USA. Agrofor. Syst. 61, 35-50.

Sharpley, A., Wang, X., 2014. Managing agricultural phosphorus for water quality: Lessons from the USA and China. J. Environ. Sci. (China) 26, 1770-1782. https://doi.org/10.1016/j.jes.2014.06.024

Sharpley, A.N., Kleinman, P.J.A., Heathwaite, A.L., Gburek, W.J., Folmar, G.J., Schmidt, J.P., 2008. 
Phosphorus Loss from an Agricultural Watershed as a Function of Storm Size. J. Environ. Qual. 37, 362. https://doi.org/10.2134/jeq2007.0366

Shi, Z.H., Ai, L., Li, X., Huang, X.D., Wu, G.L., Liao, W., 2013. Partial least-squares regression for linking land-cover patterns to soil erosion and sediment yield in watersheds. J. Hydrol. 498, 165-176. https://doi.org/10.1016/j.jhydrol.2013.06.031

Sims, J.T., Simard, R.R., Joern, B.C., 1998. Phosphorus Loss in Agricultural Drainage: Historical Perspective and Current Research. J. Environ. Qual. 27, 277. https://doi.org/10.2134/jeq1998.00472425002700020006x

Singh, G., Schoonover, J.E., Williard, K.W.J., 2018. Cover crops for managing stream water quantity and improving stream water quality of non-tile drained paired watersheds. Water (Switzerland) 10. https://doi.org/10.3390/w10040521

Sosa, L.L. De, Williams, A.P., Glanville, H.C., Jones, D.L., Marshall, M.R., 2018. Delineating and mapping riparian areas for ecosystem service assessment. Ecohydrology 1-16. https://doi.org/10.1002/eco.1928

Spivakov, B.Y., Maryutina, T.A., Muntau, H., 1999. Phosphorus Speciation in Water and Sediments. Pure Appl. Chem. 71, 2161-2176. https://doi.org/10.1351/pac199971112161

Stutter, M.I., Langan, S.J., Cooper, R.J., 2008. Spatial contributions of diffuse inputs and withinchannel processes to the form of stream water phosphorus over storm events. J. Hydrol. 350, 203-214. https://doi.org/10.1016/j.jhydrol.2007.10.045

Tang, W., Carey, S.K., 2017. HydRun: A MATLAB toolbox for rainfall-runoff analysis. Hydrol. Process. 31, 2670-2682. https://doi.org/10.1002/hyp.11185

Teufl, B., Weigelhofer, G., Fuchsberger, J., Hein, T., 2013. Effects of hydromorphology and riparian vegetation on the sediment quality of agricultural low-order streams : consequences for stream restoration. Environ. Sci. Pollut. Res. 20, 1781-1793. https://doi.org/10.1007/s11356012-1135-2

Tobler, W.R., 1970. A Computer Movie Simulating Urban Growth in the Detroit Region. Econ. Geogr. 46, 234-240.

Tramblay, Y., St-hilaire, A., Ouarda, T.B.M.J., 2008. Frequency analysis of maximum annual suspended sediment concentrations in North America. Hydrol. Sci. J. - J. des Sci. Hydrol. 53, 236-252. https://doi.org/10.1623/hysj.53.1.236

Tromboni, F., Dodds, W.K., 2017. Relationships between Land Use and Stream Nutrient Concentrations in a Highly Urbanized Tropical Region of Brazil: Thresholds and Riparian Zones. Environ. Manage. 60, 30-40. https://doi.org/10.1007/s00267-017-0858-8 
Udeigwe, T.K., Wang, J.J., Zhang, H., 2007. Predicting Runoff of Suspended Solids and Particulate Phosphorus for Selected Louisiana Soils Using Simple Soil Tests. J. Environ. Qual. 36, 1310. https://doi.org/10.2134/jeq2006.0314

Van Esbroeck, C.J., Macrae, M.L., Brunke, R.I., McKague, K., 2016. Annual and seasonal phosphorus export in surface runoff and tile drainage from agricultural fields with cold temperate climates. J. Great Lakes Res. 42, 1271-1280. https://doi.org/10.1016/j.jg|r.2015.12.014

Verheyen, D., Van Gaelen, N., Ronchi, B., Batelaan, O., Struyf, E., Govers, G., Merckx, R., Diels, J., 2015. Dissolved phosphorus transport from soil to surface water in catchments with different land use. Ambio 44, 228-240. https://doi.org/10.1007/s13280-014-0617-5

Verry, E.S., Dolloff, C.A., Manning, M.E., 2005. RIPARIAN ECOTONE : A FUNCTIONAL DEFINITION AND DELINEATION FOR RESOURCE ASSESSMENT. Water. Air. Soil Pollut. 67-94.

Wang, Q., Li, Y., 2010. Phosphorus adsorption and desorption behavior on sediments of different origins. J. Soils Sediments 10, 1159-1173. https://doi.org/10.1007/s11368-010-0211-9

Xue, Y., David, M.B., Gentry, L.E., Kovacic, D.A., 2010. Kinetics and Modeling of Dissolved Phosphorus Export from a Tile-Drained Agricultural Watershed. J. Environ. Qual. 27, 917. https://doi.org/10.2134/jeq1998.00472425002700040028x

Yang, X., Jin, W., 2010. GIS-based spatial regression and prediction of water quality in river networks: A case study in lowa. J. Environ. Manage. 91, 1943-1951. https://doi.org/10.1016/j.jenvman.2010.04.011

Yao, Q.Z., Du, J.T., Chen, H.T., Yu, Z.G., 2016. Particle-size distribution and phosphorus forms as a function of hydrological forcing in the Yellow River. Environ. Sci. Pollut. Res. 23, 3385-3398. https://doi.org/10.1007/s11356-015-5567-3

Yoshimura, T., Nishioka, J., Saito, H., Takeda, S., Tsuda, A., Wells, M.L., 2007. Distributions of particulate and dissolved organic and inorganic phosphorus in North Pacific surface waters. Mar. Chem. 103, 112-121. https://doi.org/10.1016/j.marchem.2006.06.011

Zampella, R.A., Procopio, N.A., Lathrop, R.G., Dow, C.L., 2007. Relationship of land-use/land-cover patterns and surface-water quality in the Mullica River basin. J. Am. Water Resour. Assoc. 43, 594-604. https://doi.org/10.1111/j.1752-1688.2007.00045.x

Zhang, C., Li, S., Qi, J., Xing, Z., Meng, F., 2017. Assessing impacts of riparian buffer zones on sediment and nutrient loadings into streams at watershed scale using an integrated REMMSWAT model. Hydrol. Process. 31, 916-924. https://doi.org/10.1002/hyp.11073

Zhang, L., Du, Y., Du, C., Xu, M., Loáiciga, H.A., 2016. The adsorption/desorption of phosphorus in freshwater sediments from buffer zones: the effects of sediment concentration and $\mathrm{pH}$. Environ. Monit. Assess. 188, 13. https://doi.org/10.1007/s10661-015-5018-0 
Zhou, Y., Xu, J.F., Yin, W., Ai, L., Fang, N.F., Tan, W.F., Yan, F.L., Shi, Z.H., 2017. Hydrological and environmental controls of the stream nitrate concentration and flux in a small agricultural watershed. J. Hydrol. 545, 355-366. https://doi.org/10.1016/j.jhydrol.2016.12.015

Zhu, Y., Zhang, R., Wu, F., Qu, X., Xie, F., Fu, Z., 2013. Phosphorus fractions and bioavailability in relation to particle size characteristics in sediments from Lake Hongfeng, Southwest China. Environ. Earth Sci. 68, 1041-1052. https://doi.org/10.1007/s12665-012-1806-9 